\title{
سمات الأداء التمثيلي الكوهيدي عند عبد المنعم هدبولي في المسرح "دراسة تحليلية"
}

\author{
د/ رانيا فتح الله محمد \\ أستاذ مساعد - قسم الدر اسات المسرحية \\ كلية الآداب - جامعة الإسكندرية
}

مقدمة: - مقا

في خضم ظروف عائلية طاحنة اقتحم "عبد المنعم مدبولي" مجال التمثيل، و أثبت في

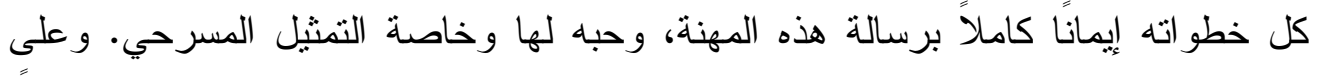

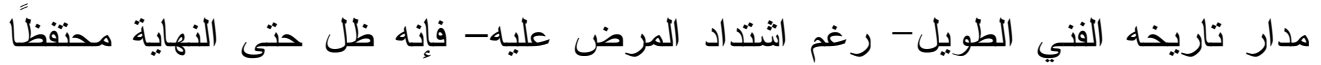

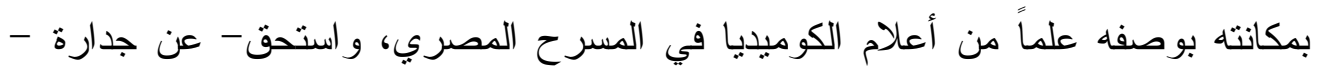
أن يكون مدرسة للكثيرين من ممتلي الكوميديا يتعلمون منه ويترك بصماته على أدائهم التمنيلي ولم لا؟ و هو المؤلف، و المخرج، و الممتل، و المعلم، و الرسام، و النحات، و والمغنئي. ولعل ما سبق كان السبب الرئيس الذي دعا الباحثة إلى تتاول "عبد المنعم مدبولي"

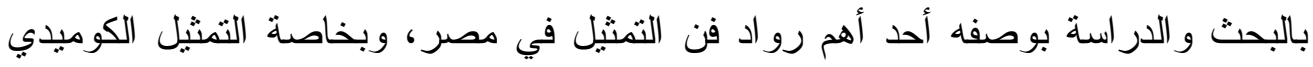

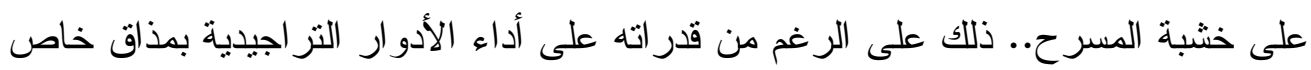

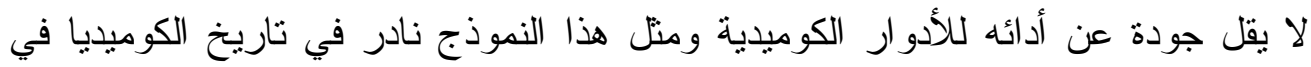

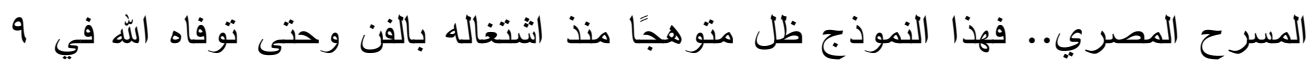

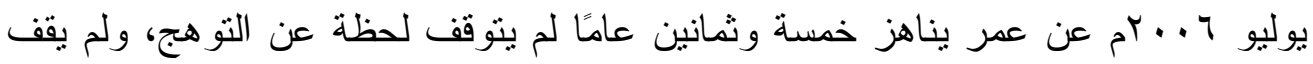

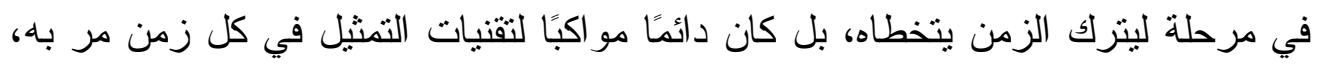
ولم يقتصر هذا التطور على مجال المسرح بل شمل السينما، و التلفزيون، و الإذاعة أيضاً،

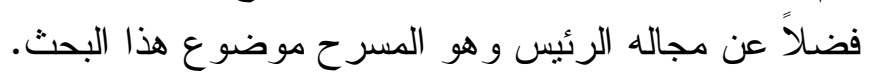

وتهدف هذه الدر اسة إلى تتاول سمات الأداء التمثيلي "عند عبد المنعم مدبولي" للوقوف

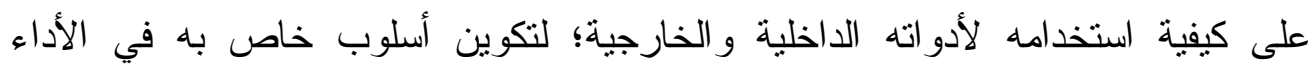

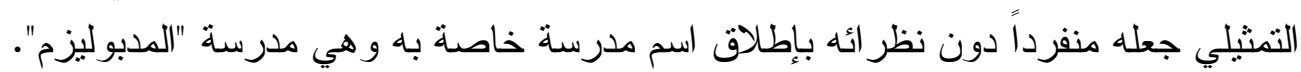

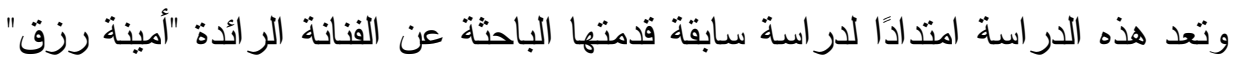

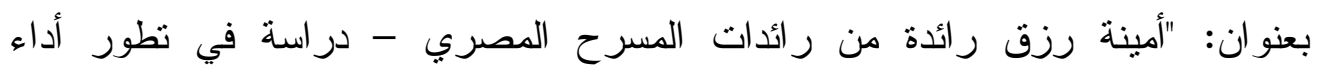
الممثل"(*). وذللك لإيمان الباحثة بأهمية در اسة أداء هؤلاء الأساتذة؛ لنتعرف على الثى المقومات 
الأساسية التي جعلت منهم رموزًا لفن الأداء التمثيلي في المسرح المصري وذللك بعدما

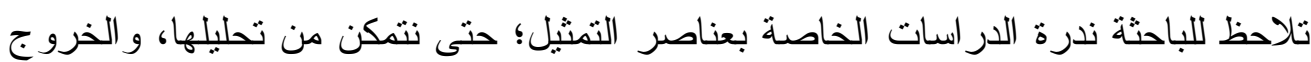
منها بنتائج تفيد الأجيال مفيدة للارسين و المشتغلين في الحقل المسرحي سعياً إلى تطوير

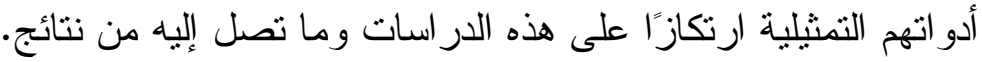

وستعتمد الباحثة في هذه الدراسة على المنهج الوصفي التحليلي لأداء عبد "المنعم

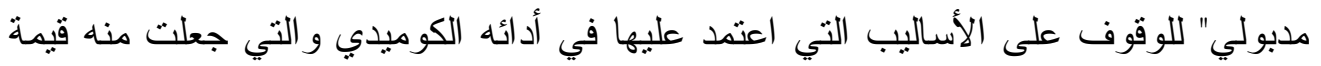

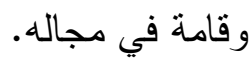

ولا "عبد المنعم مدبولي" في ب ب ديسمبر عام اب9 1، وهو الابن الثالث و الأخبر،

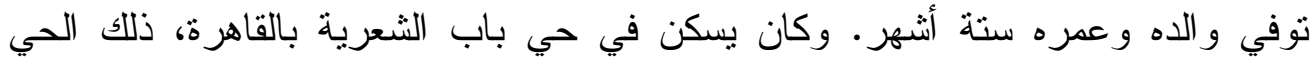

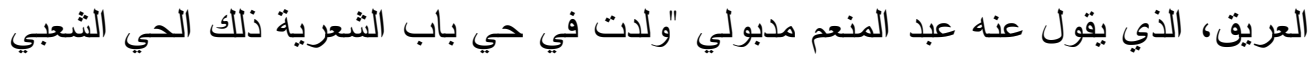

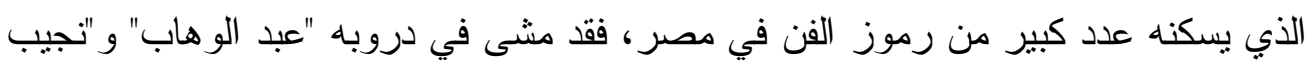

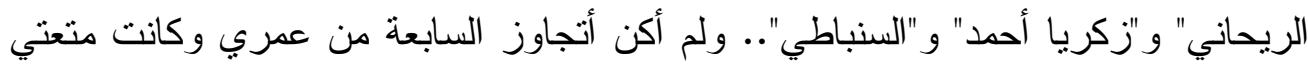

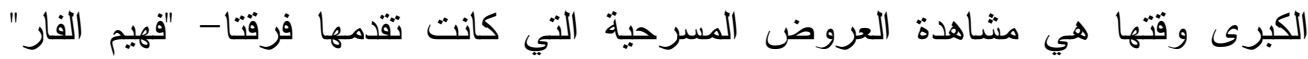

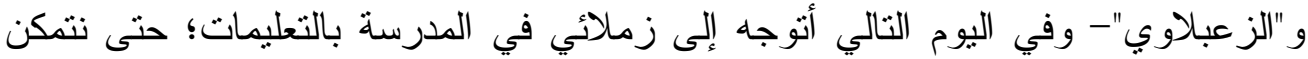

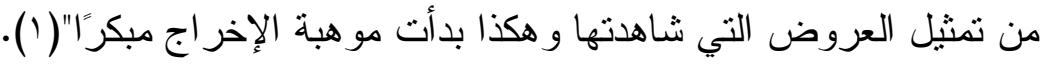
ولعل تللك التجربة وهذه الفرق التي تربى "مدبولي" على مشاهدتها وتقليدها وما كانت

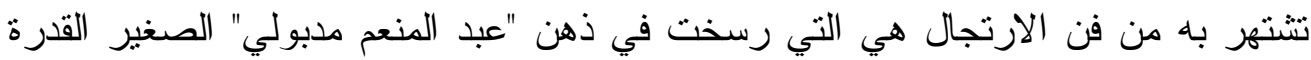

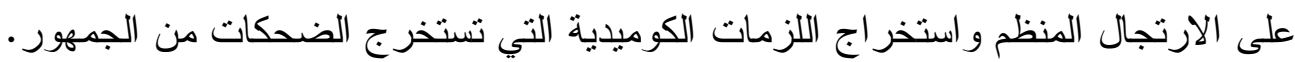
وبعد حصوله على الثهادة الابتدائية. التحق بالمدرسة الثانوية الزخرفية، ثم التحق بالعمل في قصر المانسترلي كرسام، ثم عمل مدرسًا بكلية الفنون التطبيقية في قسم النحت

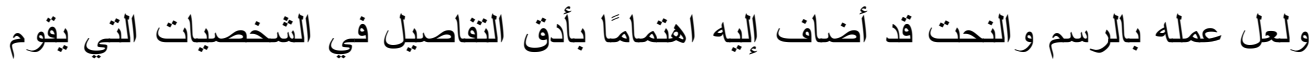
برسمها أو نحتها، وبلا شك فإنه قد اسنطاع أن بطوع هذه الاستفادة في رسم شخصياته التمثيلية التي كان يقدها على خثبة المسرح.. و لأن رغبته في التمثيل كانت شديدة فقد قرر أن يلتحق أثناء وظيفته بالمعهد العالي للتمثيل العربي (المعهد العالي للفنون المسرحية

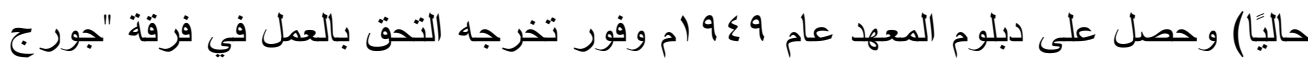
أبيض" ثم بعدها فرقة "فاطمة رشدي" كما شارك في الفترة نفسها في الأعمال الإذاعية الخاصة ببر امج الأطفال ضمن حلقات "بابا شارو "(r). 
ومن خلال عمله ببر امج الأطفال في الإذاعة شارك في فرقة "ساعة لقلبك" التي ذاع

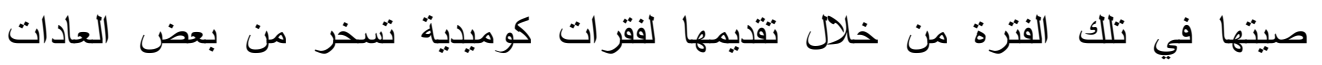

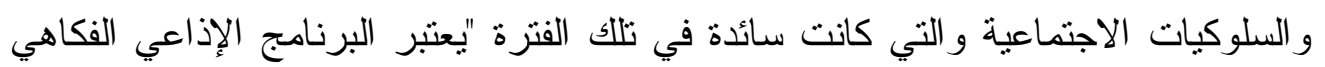

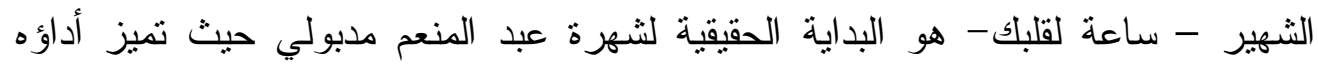
بالتلقائية و التمكن ونجح في النفاذ إلى قلوب المستمعين"(r). ومن خلال فرقة "ساعة لقلبك" عمل مع عدد كبير من ممثلي الكوميديا مثل "فؤاد

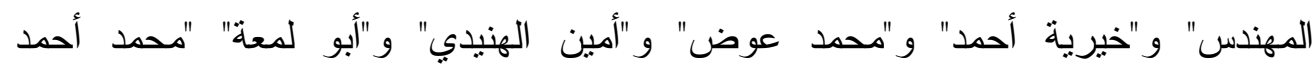

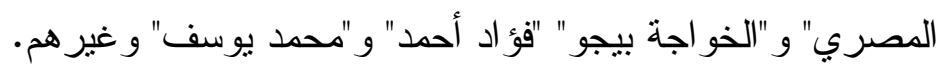

بعدها شارك "عبد المنعم مدبولي" في تكوين فرقة "المسرح الحر" التي تكونت بعد

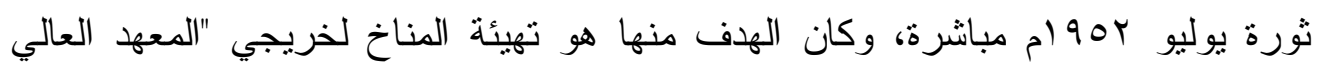

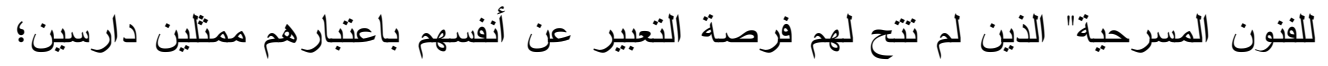

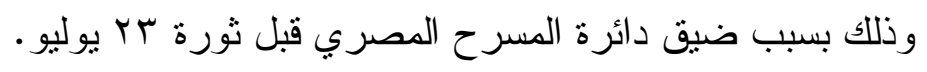

و وعند إنشاء فرق التلفزيون المسرحية عاد "مدبولي" إلى حلى طفولته وموهبته الأولى الحى

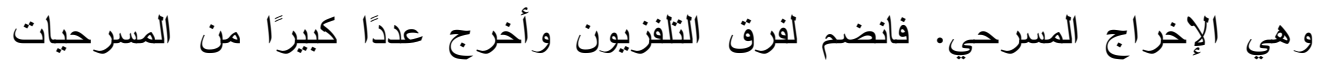

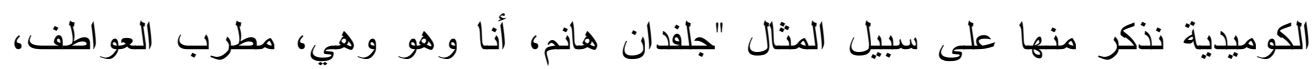

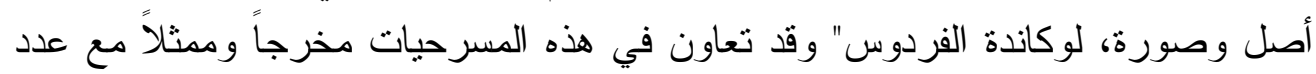

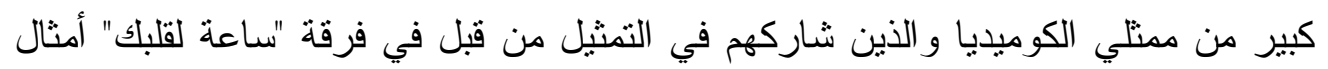

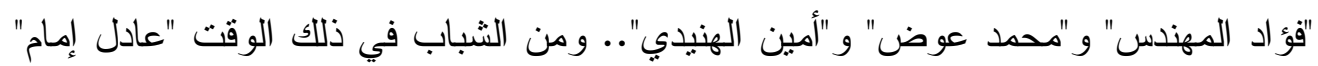

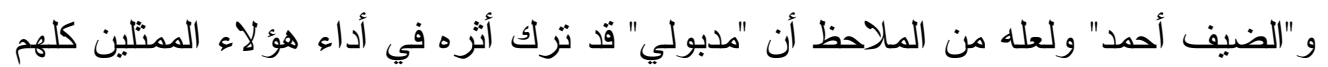

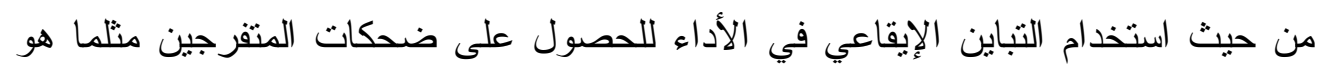

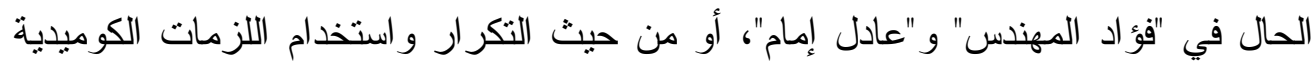
منل "محمد عوض" و "أمين الهنيدي".

بعدها شارك "عبد المنعم مدبولي" المؤلف و المنتج "سمير خفاجي" في تأسبس فرقة

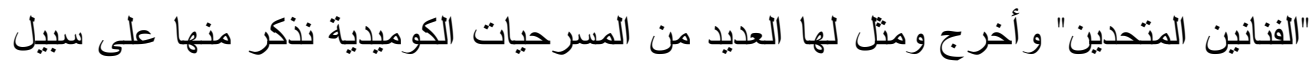

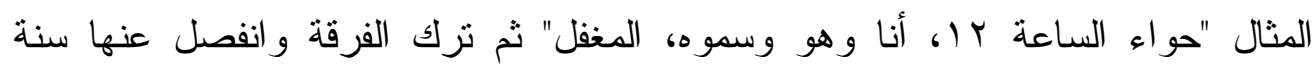

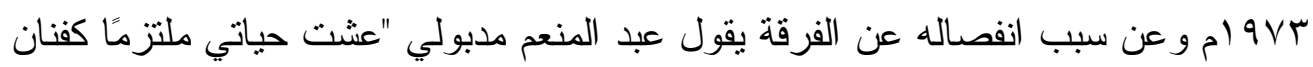
أحارب الإسفاف بكل صوره والآن - قد بلغت من العمر مرحلة بعد كفاح طويل - جعلتني

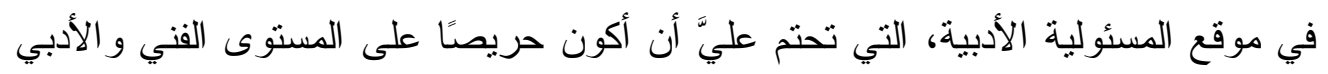
في كل عمل انشترك فيه ولما وجدت الهبوط الرخيص الذي انحدرت إلية، إليه مسرحية "مدرسة 
المشاغبين وبعد أن استهان بعض أفرادها بكل القيم الأدبية و الفنية و الأخلاقية من أجل

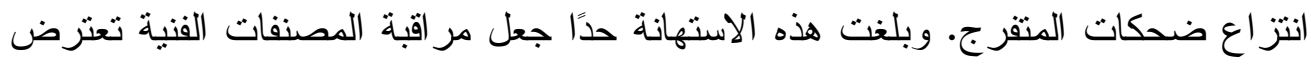

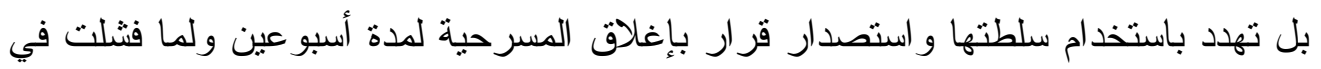

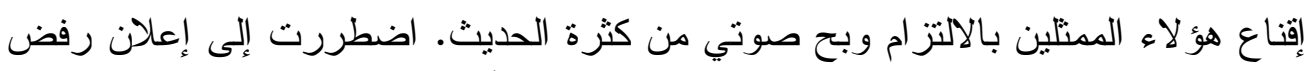
التمثيل في هذه الرواية ما لم يلتزم الممنلون، "غير أن شيئًا لم يتغير" "(؛). أما في قضية الخروج عن النص فيقول "مدبولي": "الخروج عن النص الذي يؤدي إلى الذى

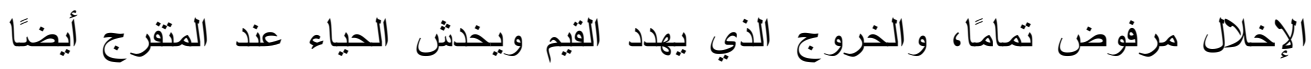

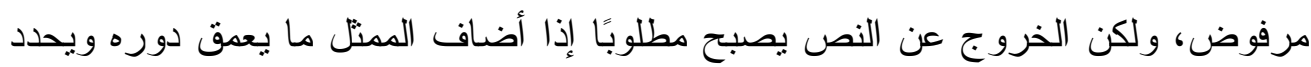

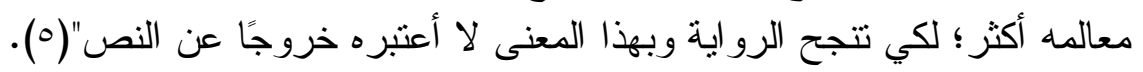

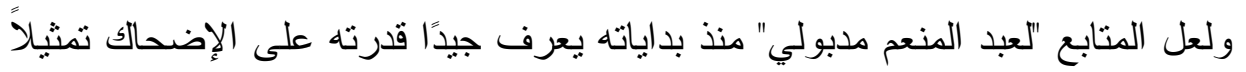

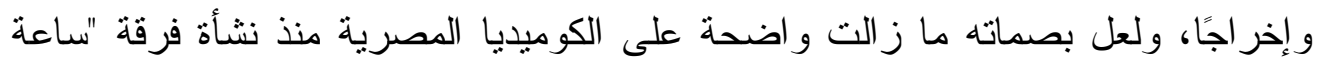

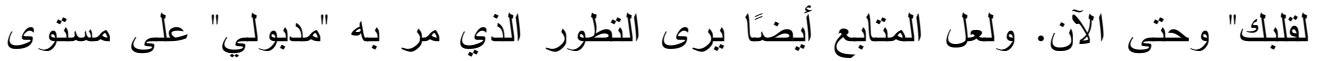

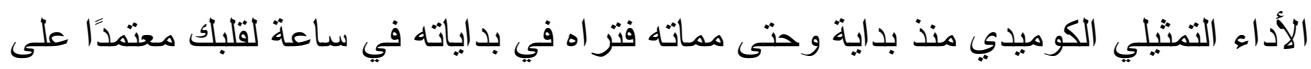

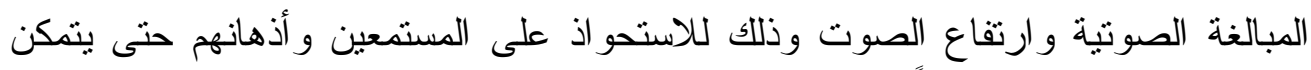

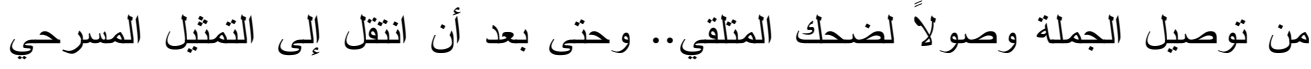

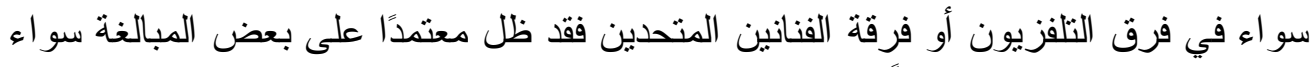

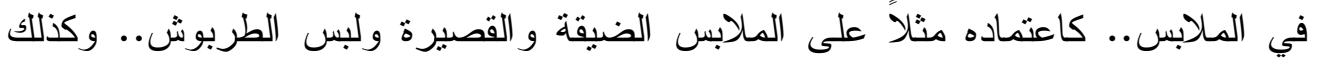

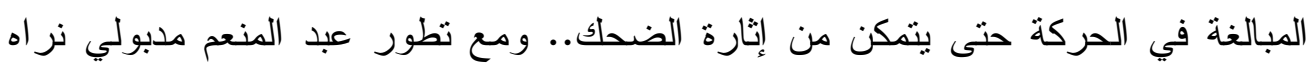

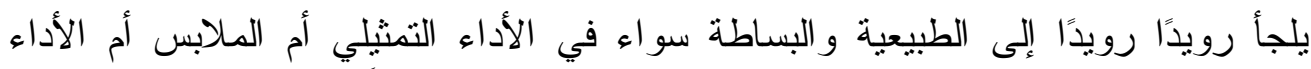

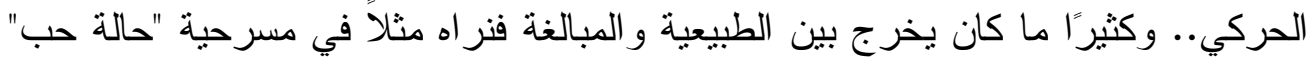

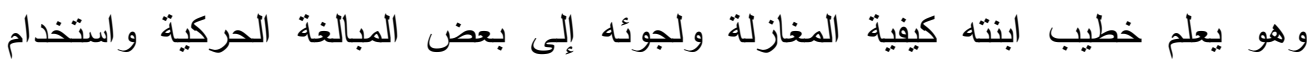

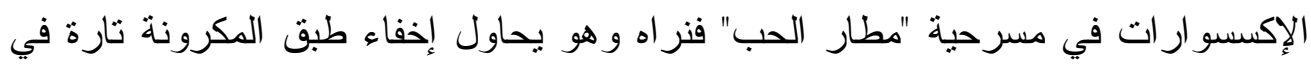

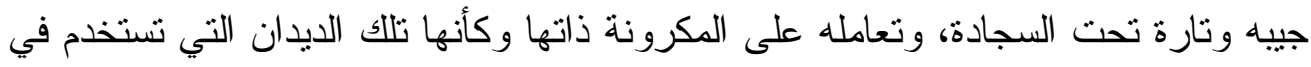

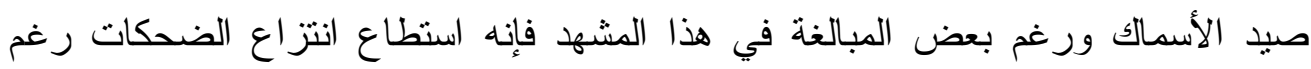

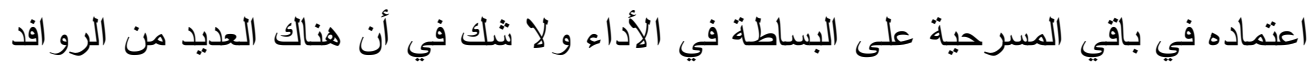

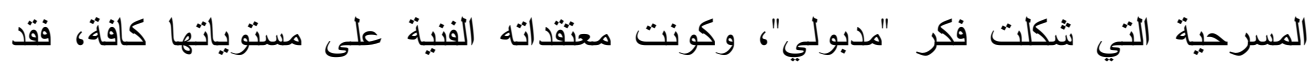

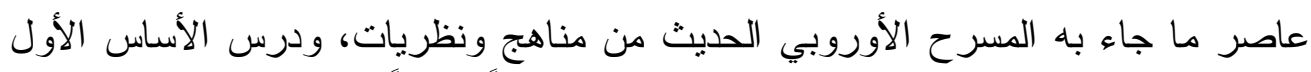

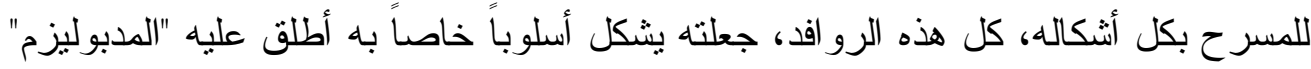

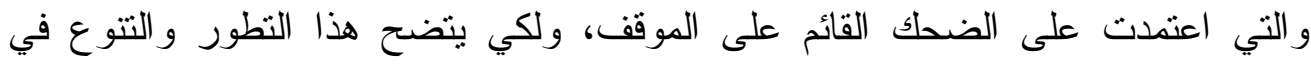

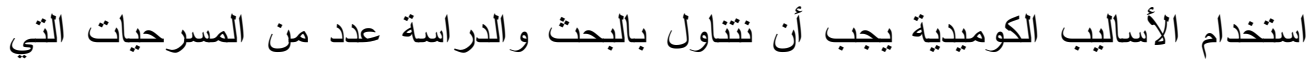
قدمها عبد المنعم مدبولي خلال فترات متفاوتة من حياته الفنية. 
وستتاول الباحثة فيما يلي تحليلاً للأداء التمثيلي للفنان "عبد المنعم مبدولي" عبر عينة

$$
\text { من أهم مسرحياته، وهي: ولئئ }
$$

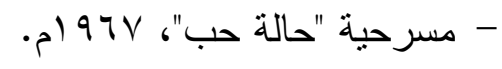

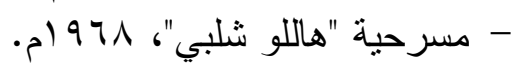

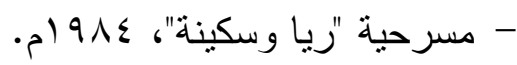

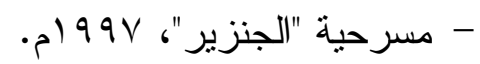

\section{أولاً: مسرحية "حالة حب":}

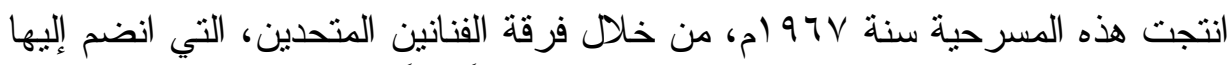

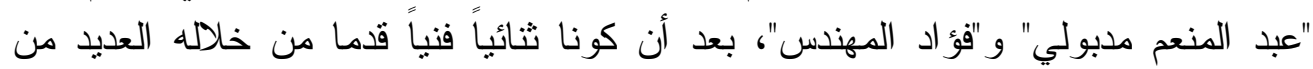

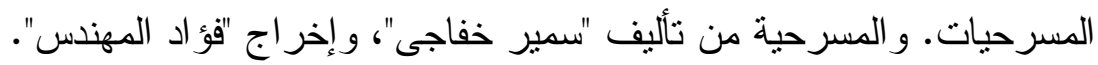

تدور أحداث المسرحية حول "رجب" "فؤاد المهندس" الثاب الخجول المجتهد في عمله "ئه

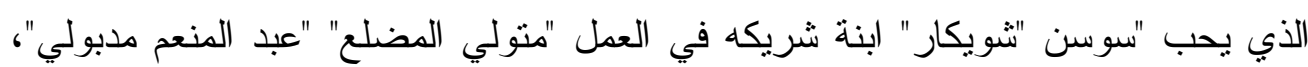

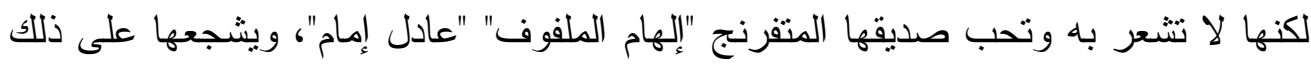

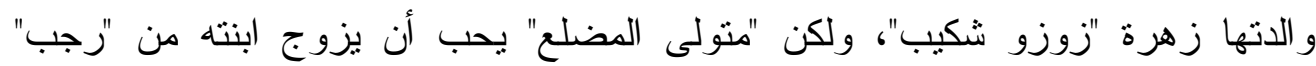

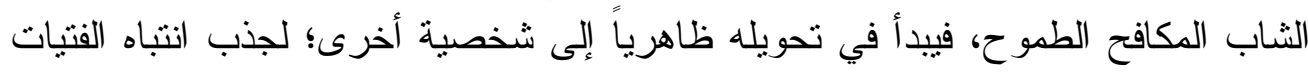

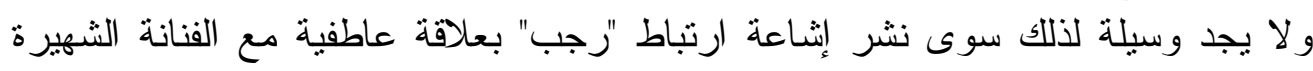

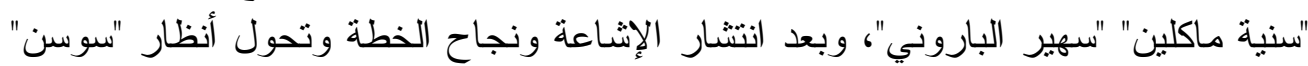

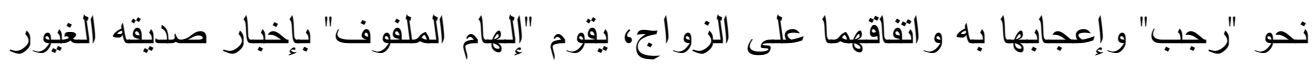

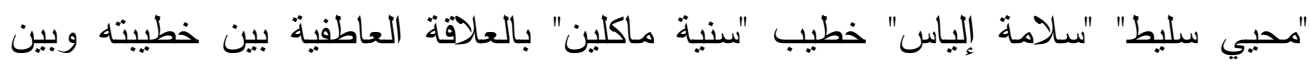

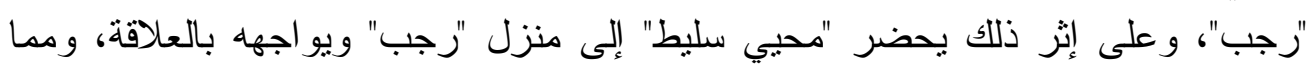

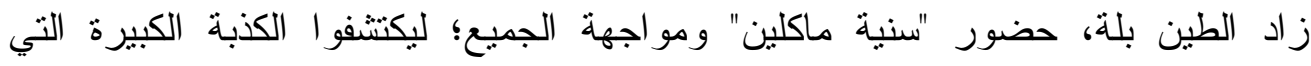
اخترعها "منولي المضلعع" في النهاية.

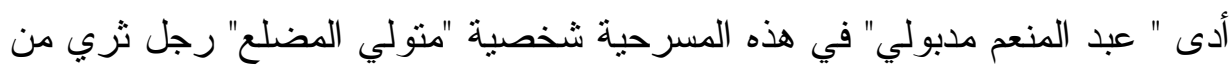

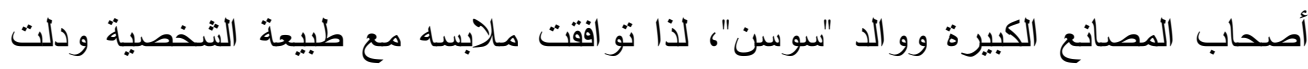

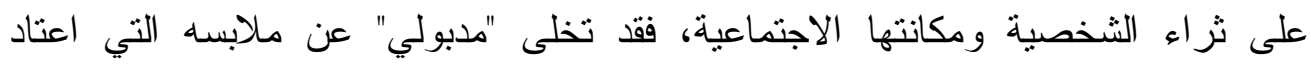

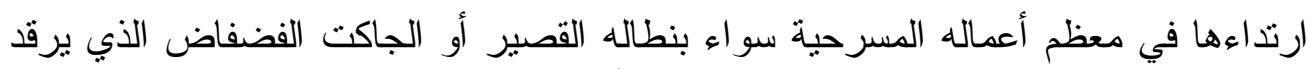

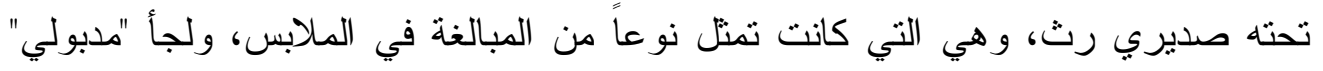

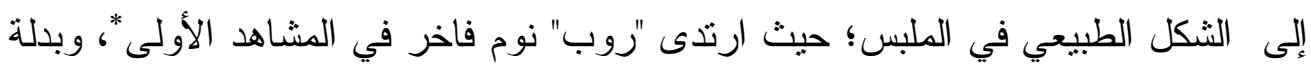

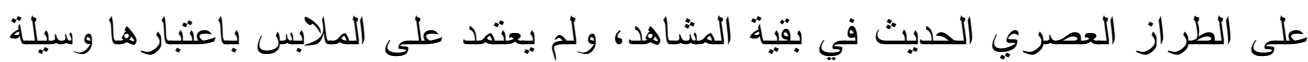


استطاع "مدبولي" في هذه المسرحية أن بمتلك أدو اته بوصفه ممثناً من صوت وجسد

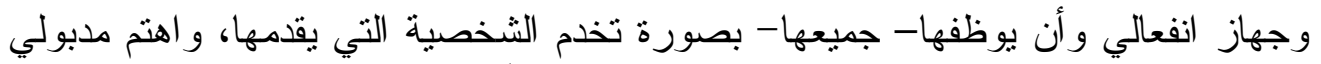

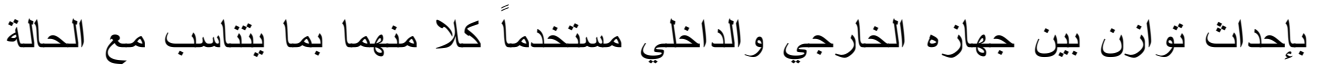

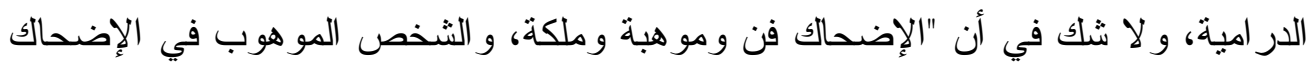

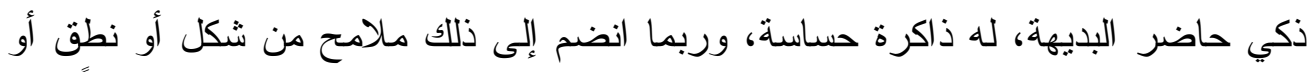

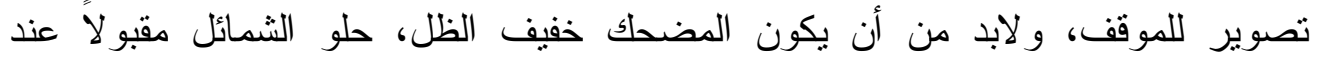

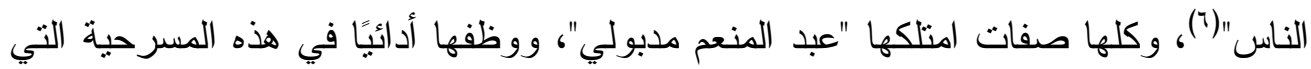

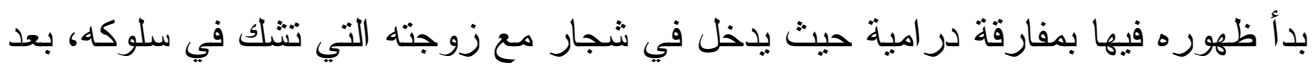

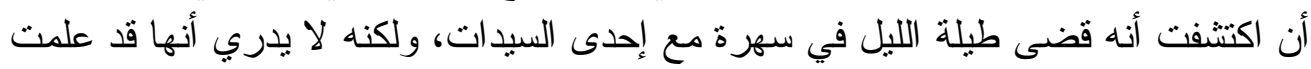
بذلك، فيحدثها عن سهرته مع صديقه "بلبع".

متولي : "أنا أتأخرت شوية في النوم... أصل أنا رجعت امبارح الساعة واحدة بالليل"("). يقولها متولي وهو يقوم بأداء تمارين الصباح بطريقة كوميدية و عندما ترد زوجته:

$$
\text { زوزو : "لا و أنت الصادق كانت الساعة أربعة"(^). }
$$

يتوقف عن أداء التمارين فجأة، ويتسمر في مكانه كالصنم ر افعًا يديه لأعلى، ويتجه

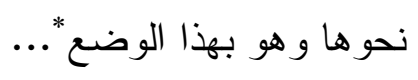

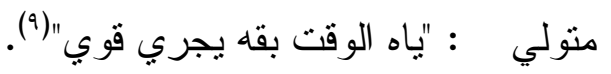
ومن هذا المشهد يتضح أن "ددبولي" قد اعتمد على ألى شكل من أنثكال المبالغة

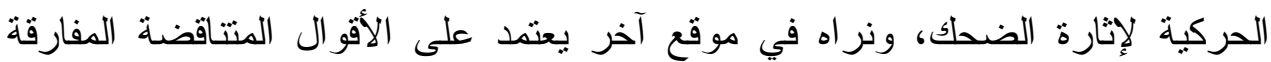

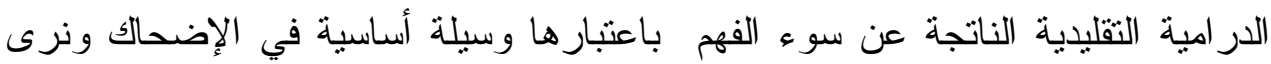

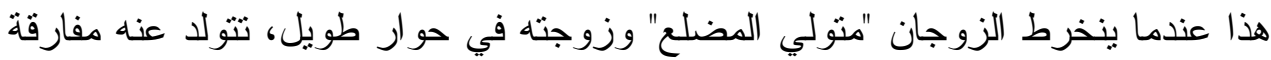
در امية تبعث على الضحك، وبخاصة عندما تسأله عن صاحبه الذي قضى فئه معه السهرة أمس.

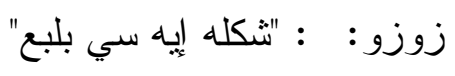

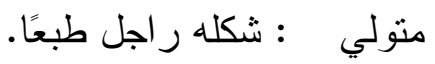

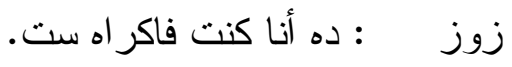

منولي : لا طبعًا ده أنا حتى كنت حاعزمه هنا امبارح لكن ما بيقدرش بطلع السلم أصله عجوز قوي.

زوز والعجوز يقدر يسهر لأربعة الصبح؟ 
منولي : (متوترً) أصل الر اجل ده فيه شباب ما حصلش.

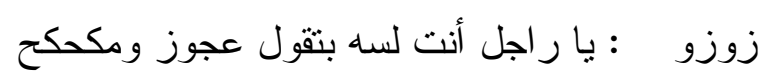
منولي :ده بالنهار بس... بس بالليل بقى بيقلب... يبقى حاجة تانية خالص... خصوصنًا

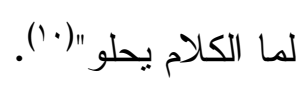

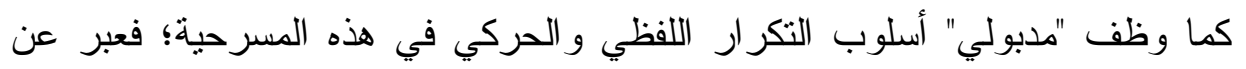

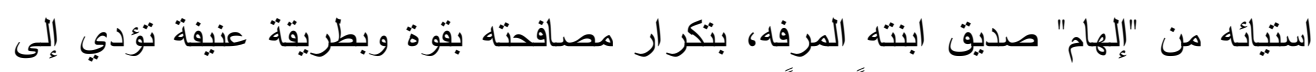

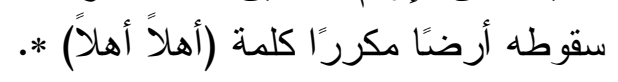

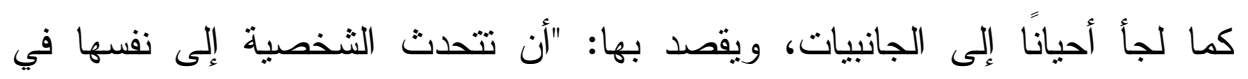

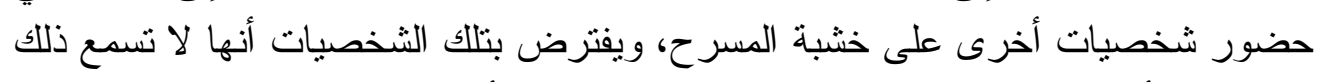

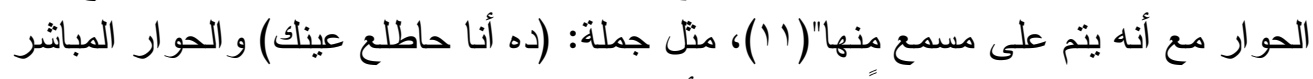

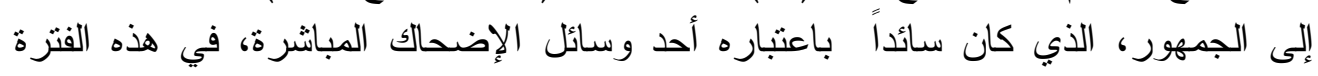
الزمنية.

كما اتجه مدبولي في بعض مشاهد المسرحية إلى أسلوب الفارس و الضحك من أجل

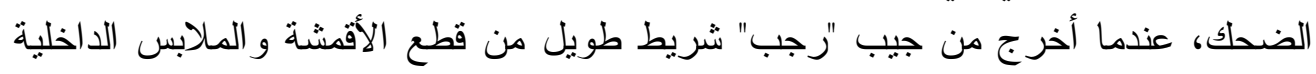
وكأنه وضع يده في جيب ساحر .

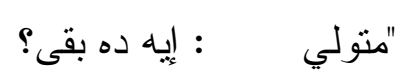

رجب : : أصل كان عندي غسيل الصبح وكنت مستعجل منولي و عامل السطوح في جيبك (يمسك بفانلة داخلية) وده إيه ده شر اب؟

$$
\text { رتول }
$$

وقد مال "مدبولي" إلى استخدام لغة الجسد التي كانت نابعة من الموقف وليست نوعًا

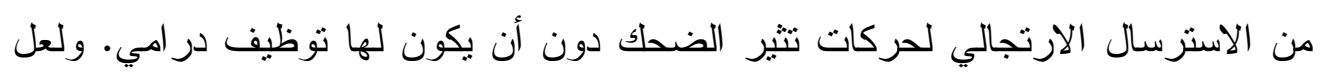
المشهد التالي الذي جمع بين متولي ورجب ومحيي سليط (خطيب سنية ماكلين) هو خير دليل على هذا. 
محيي سليط : أنا متهيألي إن علاقتهم كانت مجرد إعجاب ودي ما فيهاش حاجة

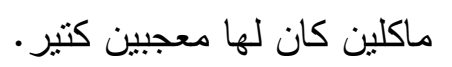

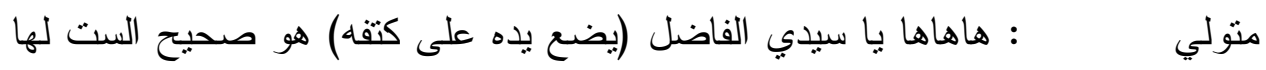
معجبين كتير لكن مالهاش غير رجب الفافل واحد.

$$
\begin{aligned}
& \text { محيي سليط : كده كده. }
\end{aligned}
$$

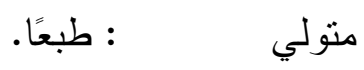

محيي سليط : حكاية زي دئا.

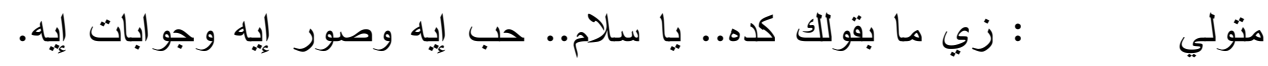

مكنتش عارفة تعمل إيه عشان نرضيه

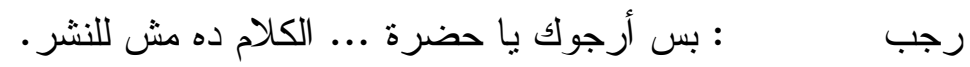

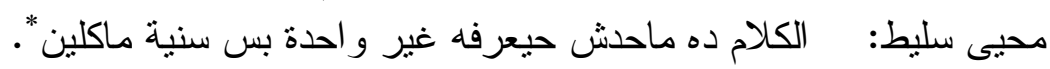

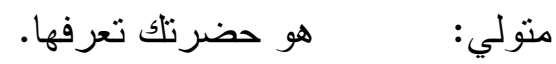

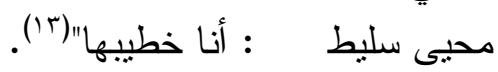

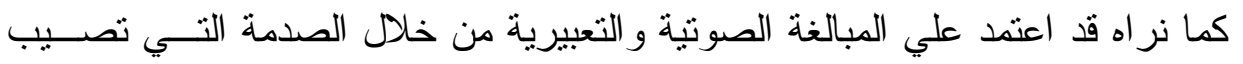

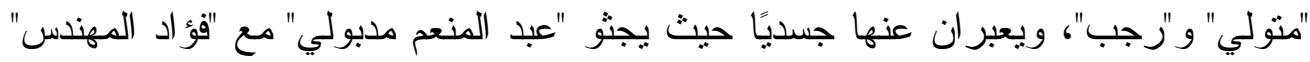
تحت أقدام خطيب المثلكة "سنية ماكلين".

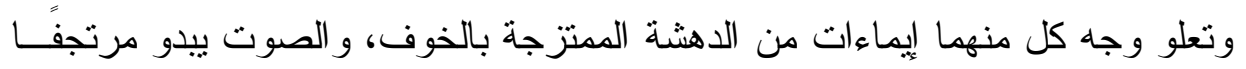

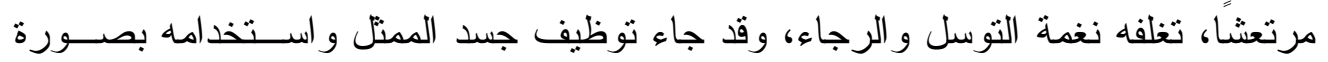

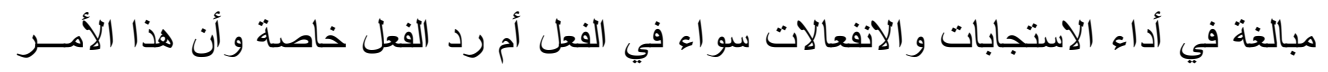

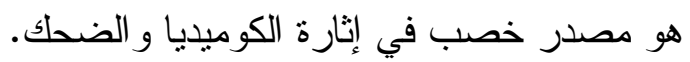

وتتنهي المسرحية بكثف الحقيقة وزو اج "رجب" من "سوسن".

ثانياً: مسرحية "هاللو شلبي"

المسرحية تأليف يوسف عوف، إخراج سعد أردش، و أنتجنها فرقة الفنانين المتحـدين

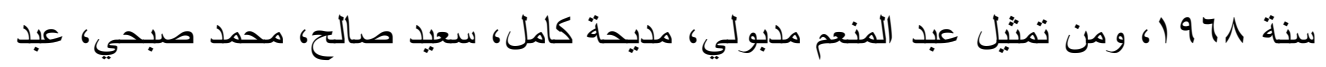
الله فرغلي، سهير الباروني.

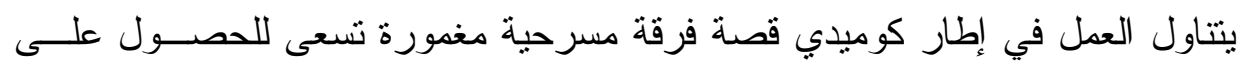

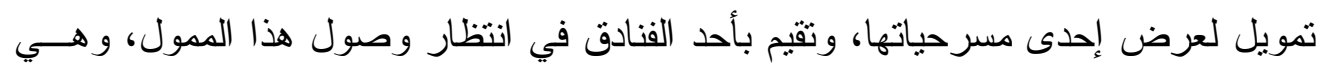

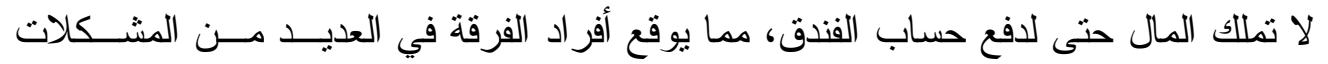

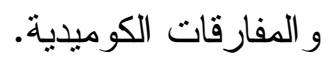


قام "عبد المنعم مدبولي" في هذه المسرحية بأداء شخصية "عنبر" صاحب الفرقة، الذي يحيك الحيل كي يتهرب من "مدكور" صاحب الفندق. وقد تتوعت صيغ الكوميديا في هذه المسرحية تتوعًا شديدًا من (الدفارقة اللفظية) إلـى الـى

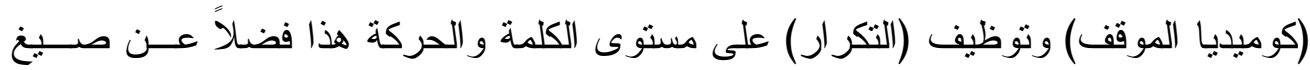

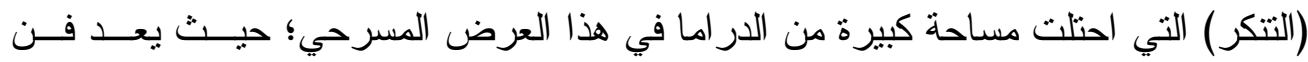

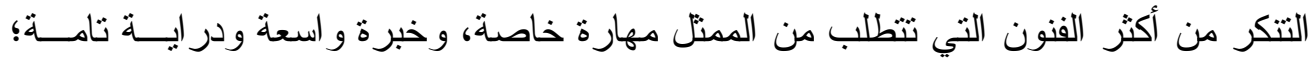

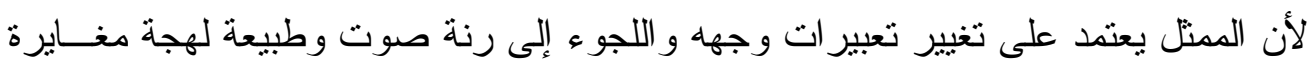

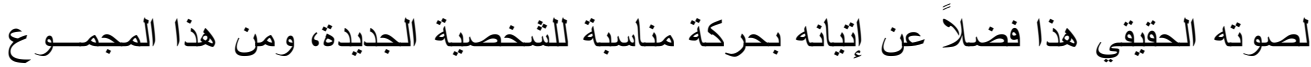

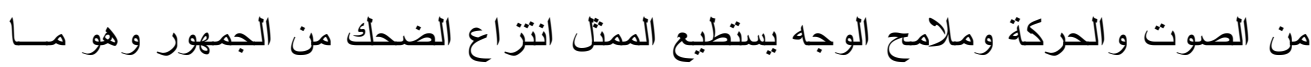

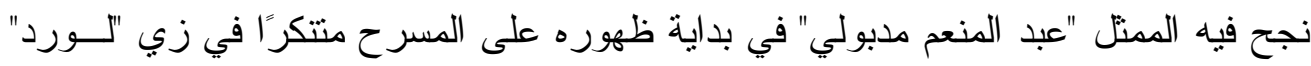

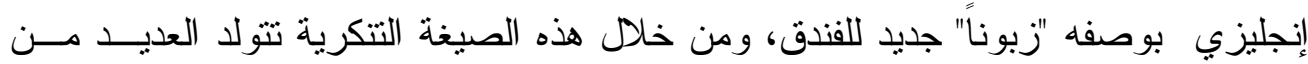

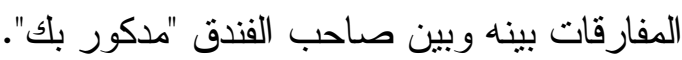

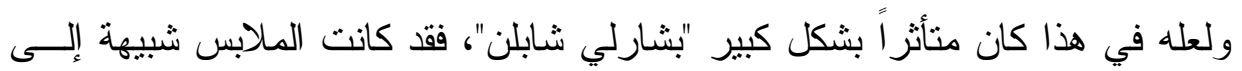

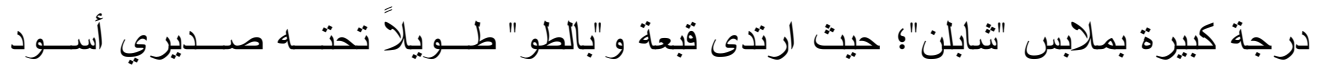

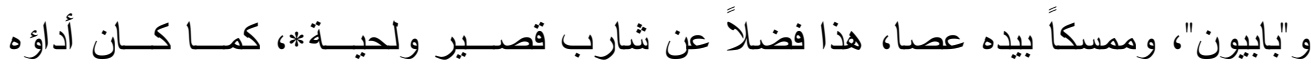

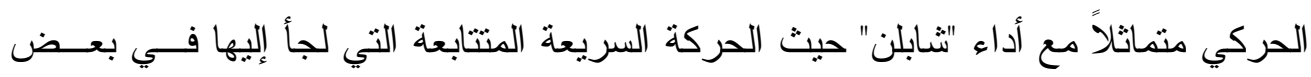

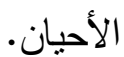

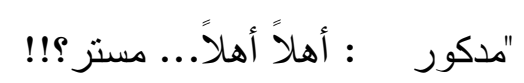$$
\text { عنبر مستر هوفمان عبد ربه. }
$$
مدكور : أهلاً وسهلاً (يصافحه بقوة). عنبر : أي... (أي بالإنجليزي يعني أنا).

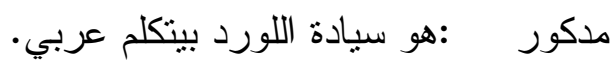

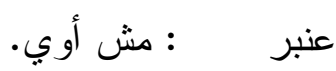

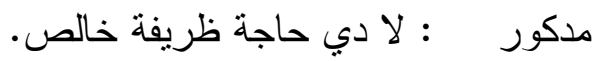
عنبر اكريفة دي تنقى خالتاك. مدكور : هو سيادة اللورد جه مصر قبل كده؟

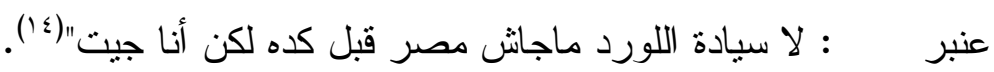




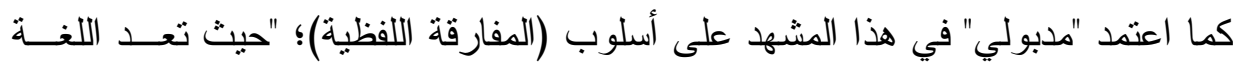

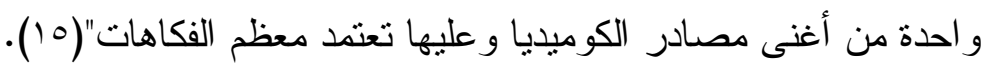

$$
\text { منبر }
$$

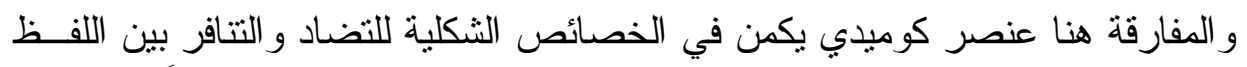
المنطوق و اللفظ المنو ارى، و استخدام لفظة يمكن تفسير ها بطريقتين مختلفتين تماماً.

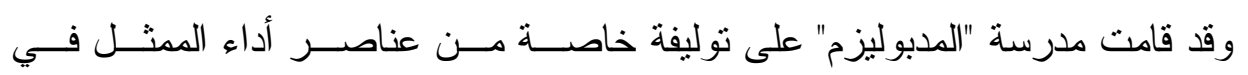

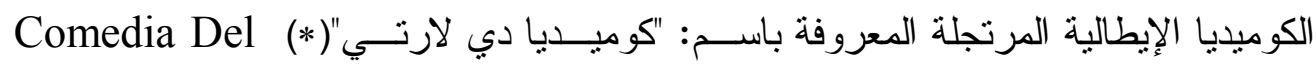

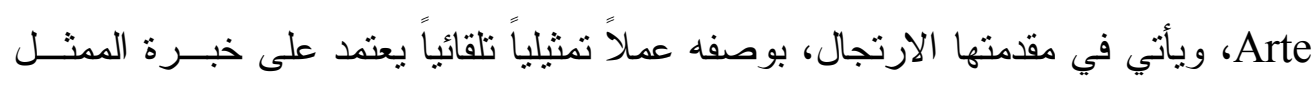

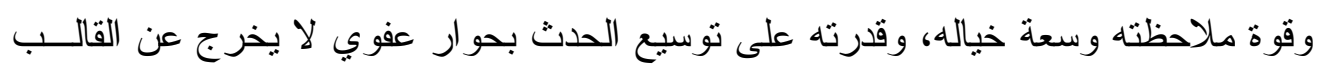

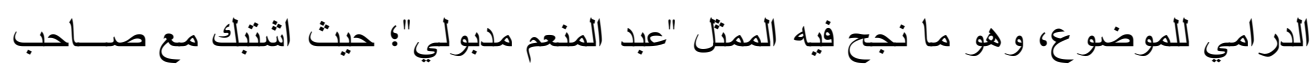

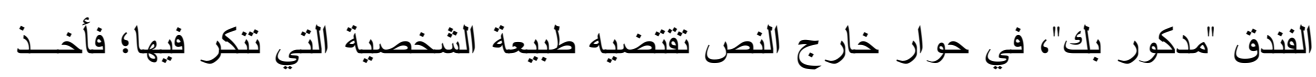
يتحدث الإنجليزية بشكل فكاهي.

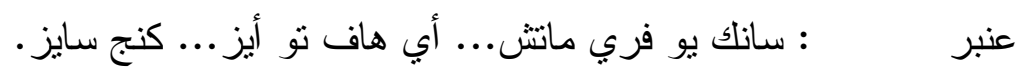

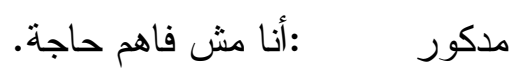

$$
\begin{aligned}
& \text { عنبر أي وونت سليب... أي وونت إيت. } \\
& \text { أي وونت... أي وونت!!! ... هي استحمى بعني إيه بالإنجليزي. }
\end{aligned}
$$

$$
\text { منبر }
$$

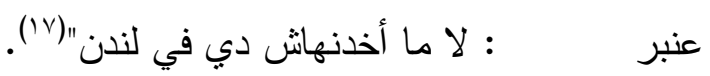

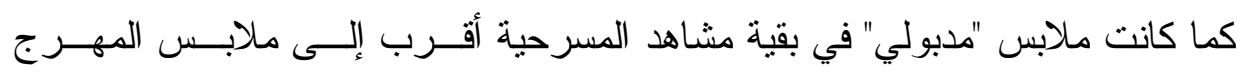

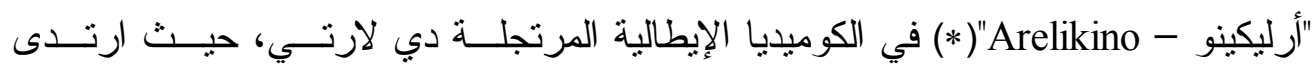

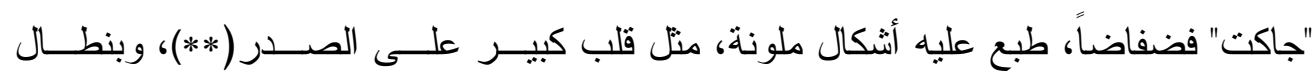
قصبر ، و عصا صغيرة. 
كما لجأ مدبولي في أدائه التمثيلي في هذا العرض إلى أسلوب (التكرار) على مســتوى

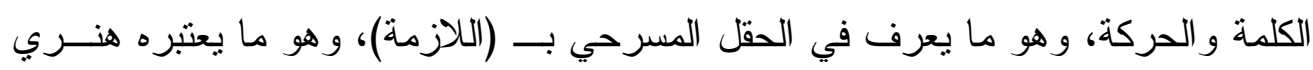

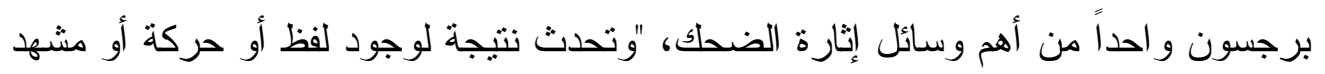

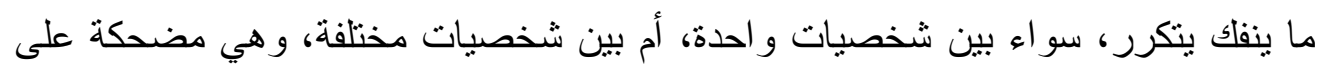

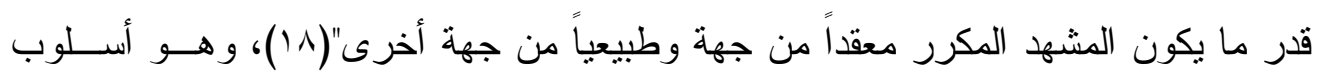

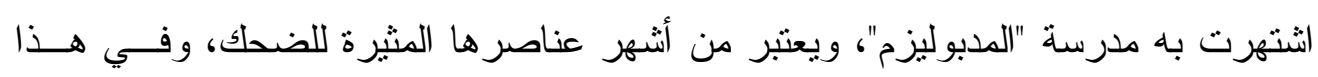

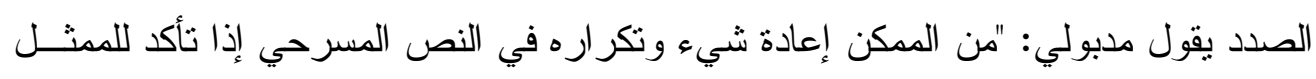

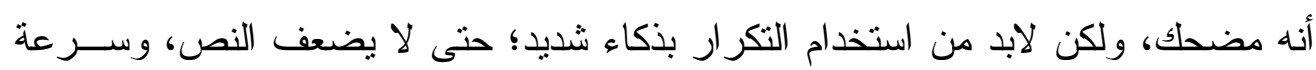
البديهة، و الذهن الحاضر أمر ضروري بجانب الابد من البساطة و التلقائية"(9 (19).

فعلى مسنوى الحركة وظف "مدبولي" أسلوب (التكرار) من خلال فقد اتزانــهـ مـــراراً وتكراراً عند اتكائه على العصا التي لازمته في مشهد اللورد الإنجليزي(*).

أما على مستوى (التكر ار اللفظي) فقد لجأ إليه "مدبولي" في معظم مشاهد المسـرحية،

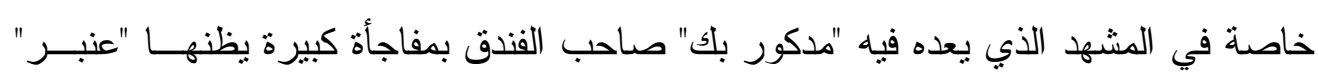

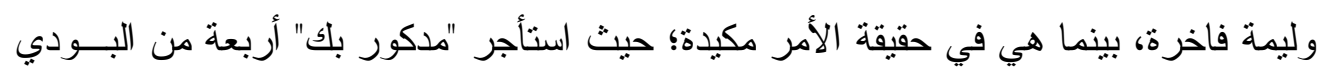

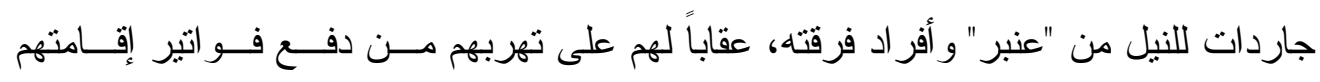

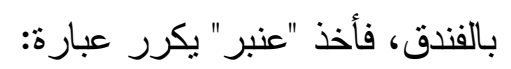

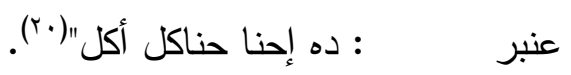

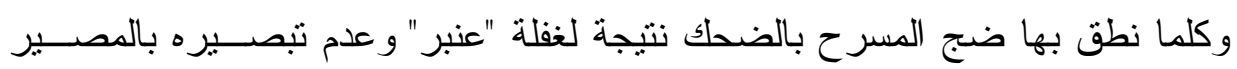

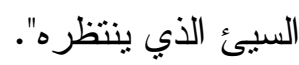

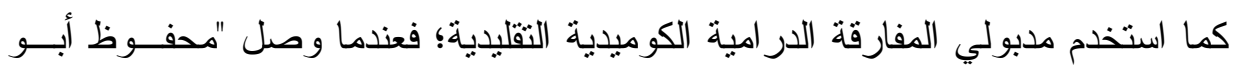

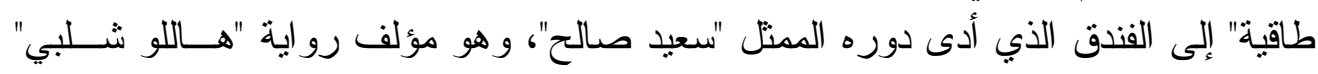

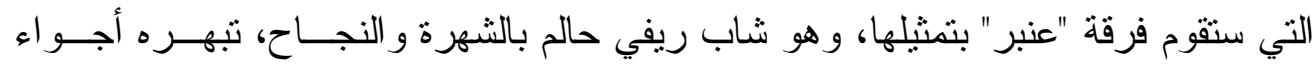

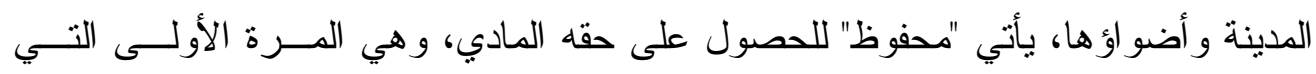

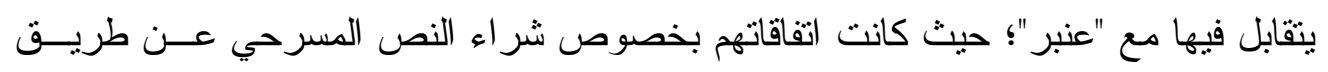

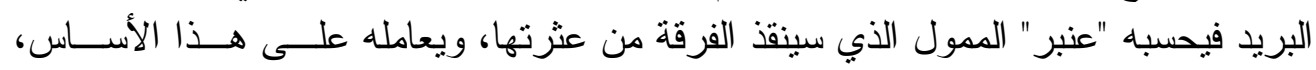

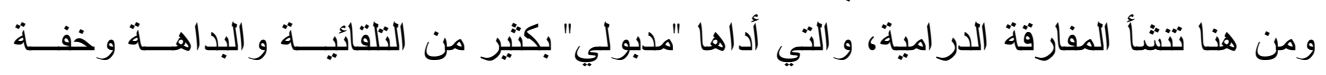




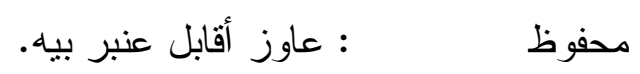

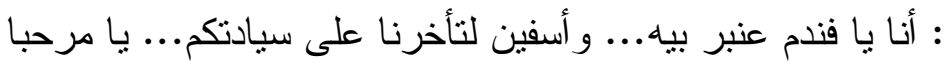

عنبر

بمن حبا ودبا وقالت له العظماء كاف و لام وباء... على فكرة فيه

ناس جم عرضوا عليا يصرفو ا على المسرحية دي ألوفات...

أنا دافع للمؤلف لوحده ألفين جنيه.

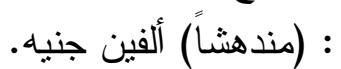

محفوظ

: ألفين جنيه ورقة واحدة قد كده هو ..

عنبر

: افتكر كويس بمكن تكون غلطان في صفرين.

محفوظ

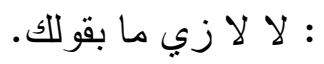

عنبر

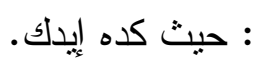

محفوظ

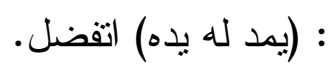

عنبر

: لا هات حاجة من تحت الحساب.

محفوظ

: البيه بيحب يهزر.

عنبر

: لا لا و النبي أنا بأكلم جد.

محفوظ

: أنا أول مرة أثنوف ممول عايز يقبض.

عنبر

: ده أستاذ محفوظ المؤلف"(r(') :

ابنة عنبر

الفندق

هنا تثور ثائرة "عنبر" ويأتي بحركات جسدية كماولة نزع شعر رأسه، أو تقطيع

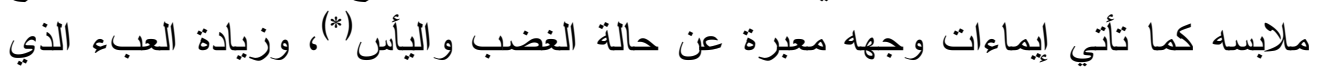

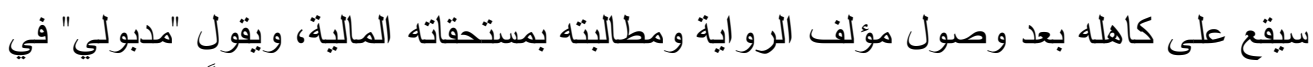

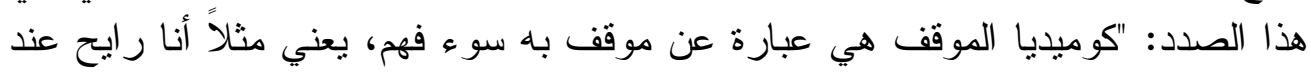

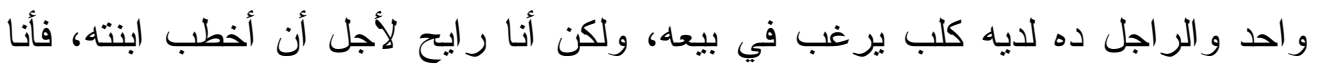

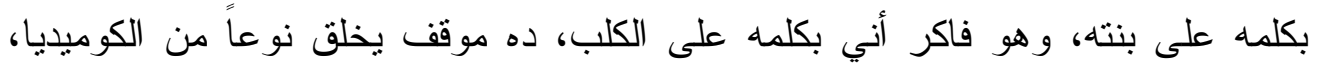

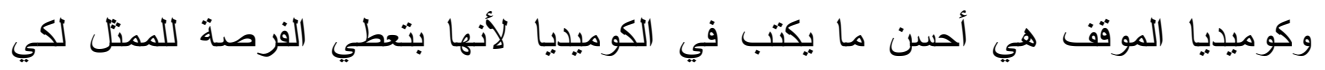

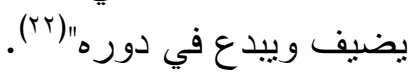

وقبل أن يكتشف "عنبر" حقيقة شخصية المؤلف "محفوظ أبو طاقية"، وظنه أنه الممول كان يكرر جانبياً، ودون أن يسمعه:

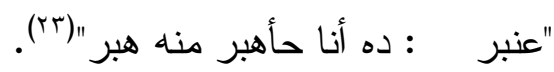

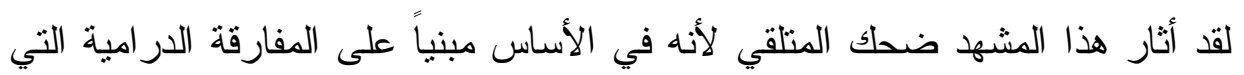
نولات من جهل "مدبولي" بحقيقة الثخصية، وتعامله معها بوصفها شخصية أخرى. 
وتتتهي المسرحية بنجاح "عنبر" و أفراد فرقته في عرض مسرحيتهم التي نالت استحسان الجمهور، "و المسرحية في عمومها تبرز كفاح الفنان ليصل إلى الجماهير ويؤدي فئهي

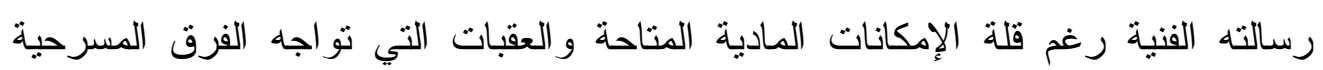
الناشئة" (ب (r).

\section{ثالثاً: مسرحية "ريا وسكينة"}

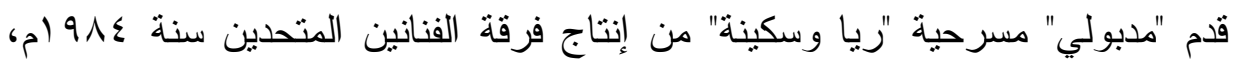

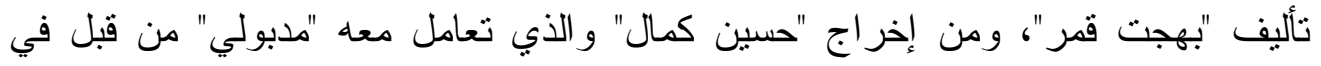
مسرحية "بمبه كثر"، و عنه يقول "مدبولي": "مخرج فاهم وواع ومن وميزته الكبرى هي كيفية

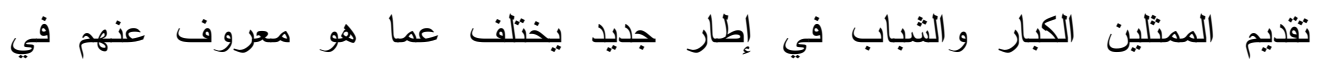

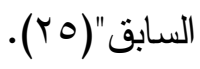

تدور المسرحية حول حادثة حقيقية حدثت في الإسكندرية من خلال شقيقتن فقيرتين

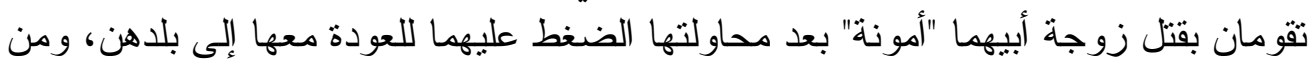

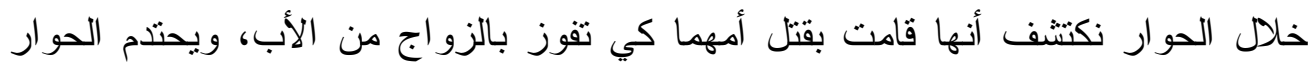

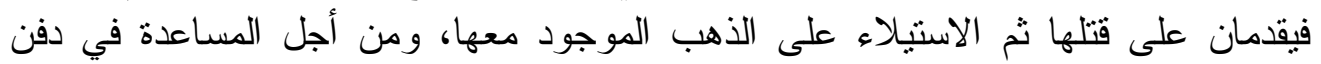

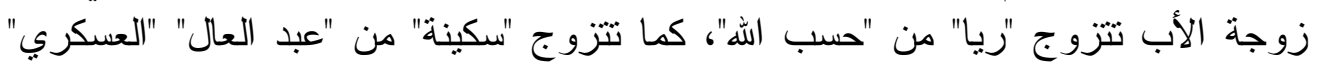

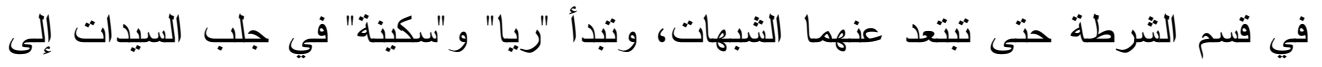

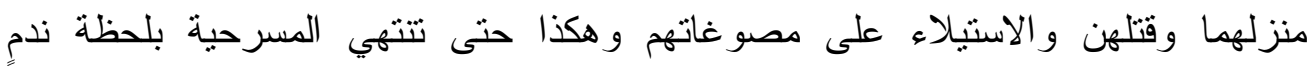

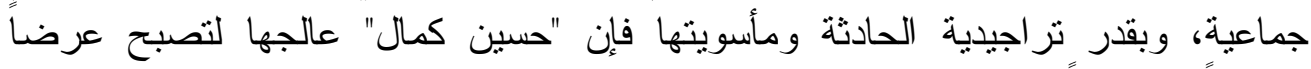

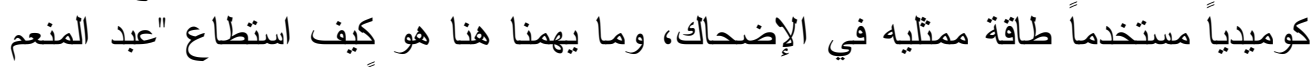

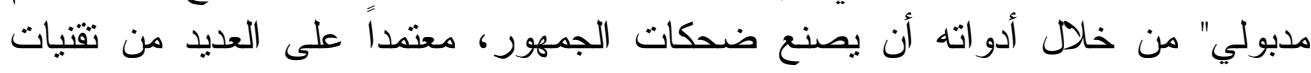

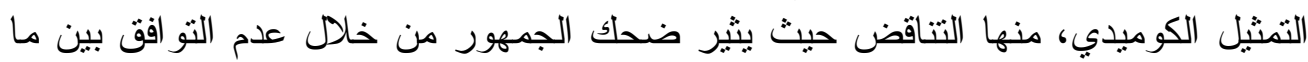

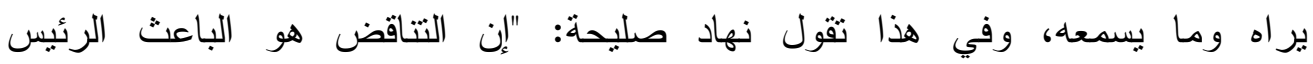
للضحك"( بr)؛ ففي مشهد حفل زوراج "ريا" من "حسب الله" يتوجه الأخير إلى المأذون الكهل العجوز ويسأله في منتهى الجدية(*):

" حسب الله : إيه با مو لانا مش تشد حيلك وتتجوز؟ المأذون لما أكون نفسي الأول.

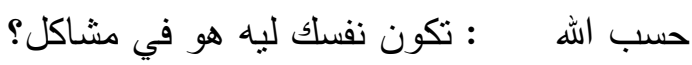
المأذون أخلص جيش. حسب اله هما رفعو اسن التجنيد لنسعين سنة؟؟!!"(YV). 
كما لجأ "عبد المنعم مدبولي" إلى (كو ميديا العاهات) باعتبار ها مصدر اً مــن مصــادر

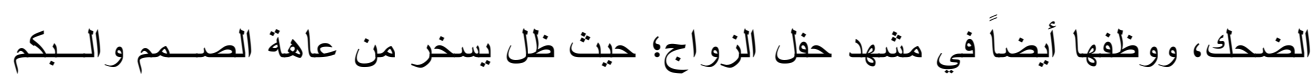
التي يعاني منها أحد الثهود الذي كان يعمل في الأصل مطرباً في فرقة "حسب الله".

$$
\begin{aligned}
& \text { " حسب الهه : ده مش غريب ده كان شغال معايا. }
\end{aligned}
$$

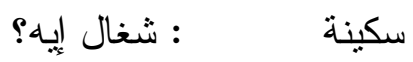

$$
\begin{aligned}
& \text { حسب الله مطرب. }
\end{aligned}
$$

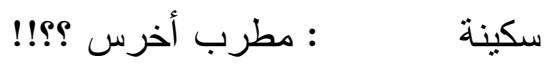

حسب الله قبل ما يتخرس.... الخرس جاله في حادثة.

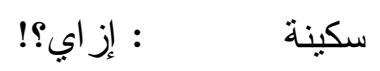

حسب اله الو اد ده طول عمره مطرب، وملعلع عقبال ما تشوفي و لاد الحبايب".

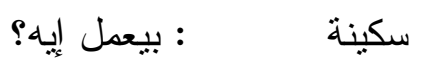

حسب الله الو اد ده كان يقول يا ليل قبل العشاء يخلص منها تاني يوم الضهر، يا ليل بس... يا عين يقولها في فرح تاني، لحد ما جه فرح منيل فيل بنيله

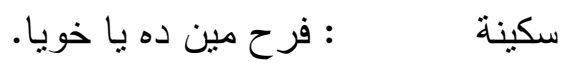

$$
\begin{aligned}
& \text { حسب اله فرح و احد جز ار، قال يا ليل ما قالش يا عين. } \\
& \text { سكينة ليه؟ }
\end{aligned}
$$

حسب اله الو اد ده من عادته لما يلعلع لسانه يطلع لبرة ويدلدل، بس لسانه مش زي لسانا،

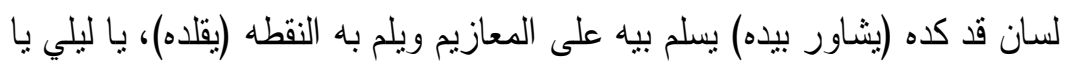

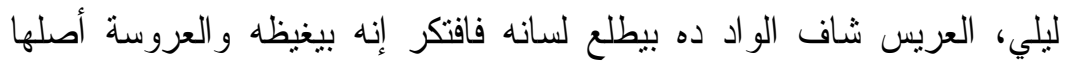

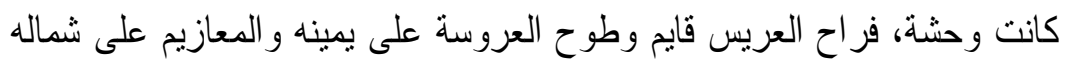

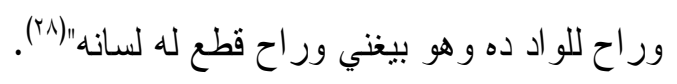

كما يوظف "مدبولي" أسلوب "القفلة" فيكسب المتلقي الثعور بالتقوق نتيجة معرفته مــــانه

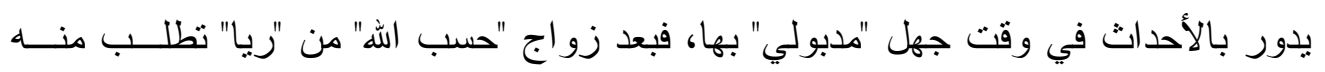

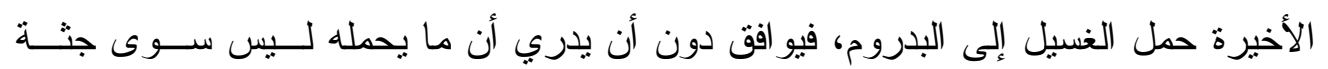
"أمونة" التي قامت "ريا وسكينة" بقتلها. 
أنا عايز الك با حسبو يا حبيبي تخلصني من الغسيل اللي على الكنبة دي. " ريا : الغسيل بس ده أنا أثنيل الغسيل و أصحاب الغسيل و الكنبة..... حسب الله : تعالى (جانبيا) و لا كأننا قتلنا قتيل.

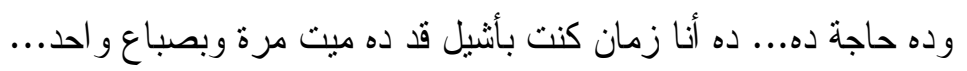
حسب اله زمان أنا.... زمان بقه... ها دها ها ها دان

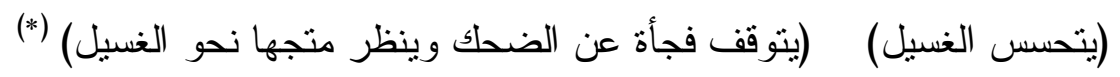
أيه ده.. هو غسيلكم معضم كده له....

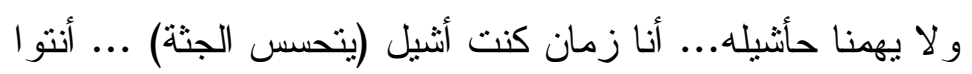
غاسلين بالوظة... (يتحس الرأس).... ها ها ها يا لؤمة غاسلين

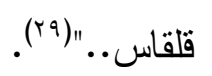

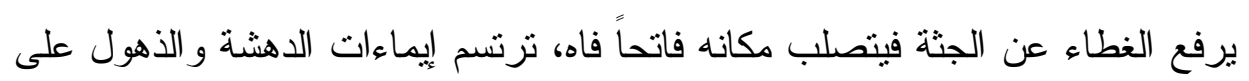

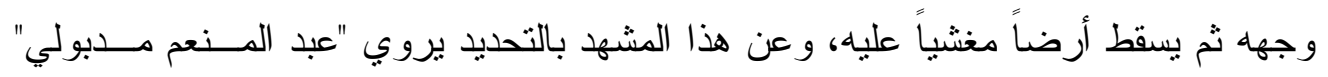

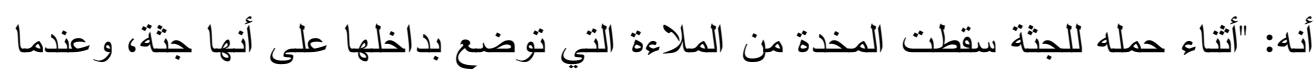

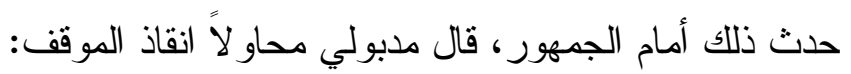

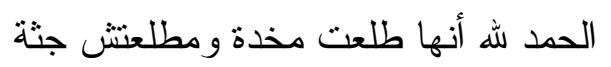

$$
\text { كان الو احد راح في داهية"(·)". }
$$

وضحك الجمهور ، وهذا إن دل على شيء، إنما يدل على سرعة بديهة الممثل وتمتعه بالحضور الذهني.

كما لجأ "مدبولي" إلى تقنية (التكرار اللفظي والحركي) (اللازمة)، و واستخدمها في

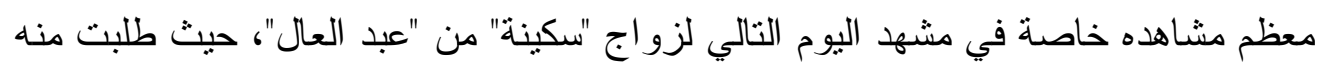

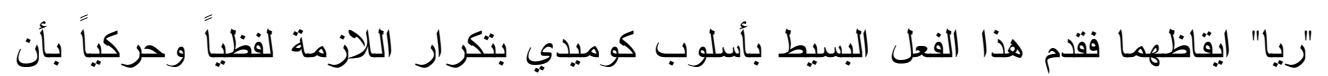

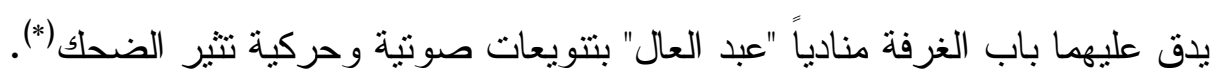
ورغم المفارقات و النتاقضات التي كانت أساساً لخلق الضحك، فإن "عبد المنعم مدبولي" قد استثمر طاقته التمثيلية في المشاهد التي تعتمد على المشاعر الإنسانية، ولجأ

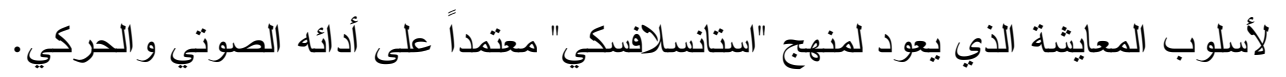




\section{وتضح هذا جلياً في المشهد التالي:}

حسب اله أنا بقيت منكم وعليكم، لكن عبد العال بقه زي الكلب السعران وأول ما حيعض حيعض صحابه، و علاج الكلب السعر ان حاجة و احدة... قتله.

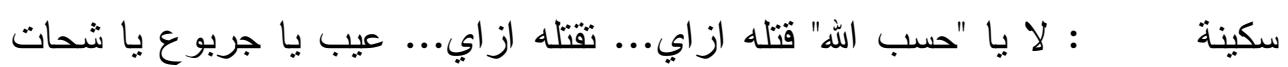

$$
\text { (تصفعه على وجهه). }
$$

حسب الله غلط يا "سكينة".. غلط اللي أنتي عملتيه ده....

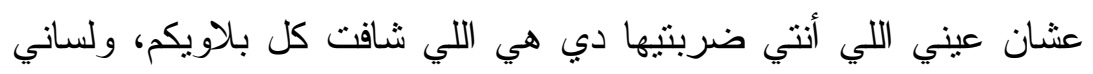

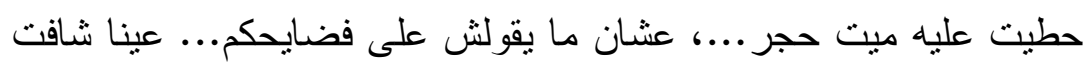

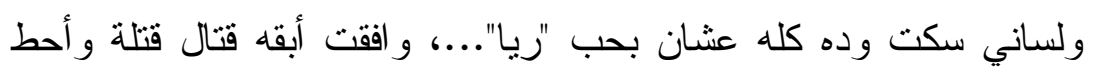

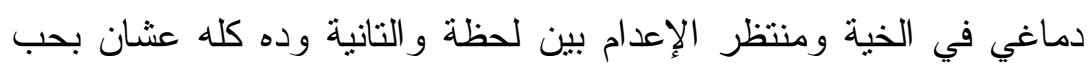

$$
\text { "ريا" و عارف إنها ما بتحبنيش. }
$$

$$
\text { "حسب الله". }
$$

حسب اله : استتي يا "ريا" أختلك بتعايرني بأني جربوع وشحات، أنا كنت باشحت عشان لقمة عيش بس كنت باكل لقمة عيش شريفة وأنام مرناح البال

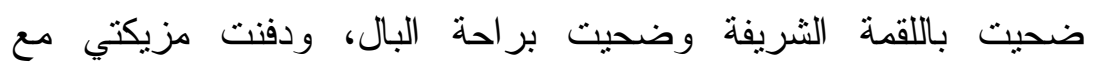

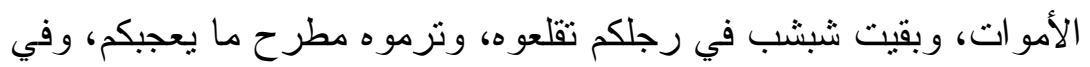

$$
\text { الآخر بانضرب بالقلم على وشي" ('ا"). }
$$

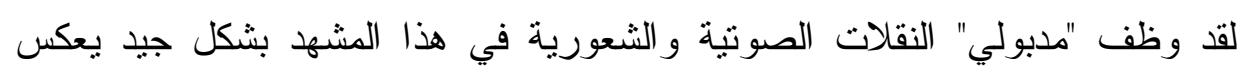

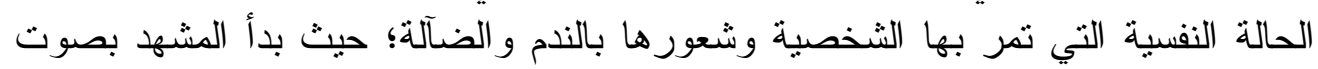

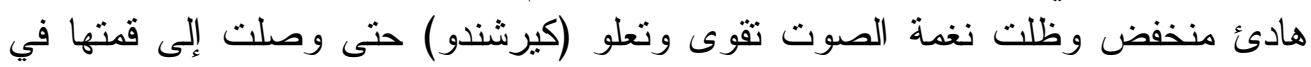
جملة (وفي الآخر بانضرب بالقلم على وشي) (*). و أكمل "مدبولي" المشهد بصوت متهدج يجسد مشاعر الحزن التي تعتريه.

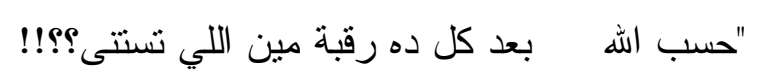

رقبتي أنا... أيوه رقبتي أنا.... أنا اللي إديت ومابن وماخدنش أنتم أخدتو الفلوس

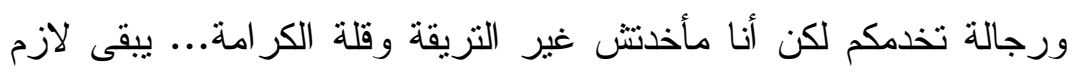

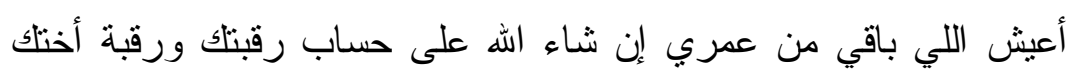

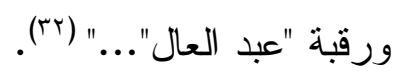




\section{رابعاً: مسرحية "الجنزير"}

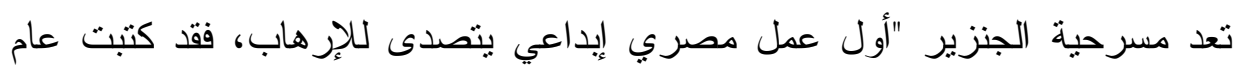

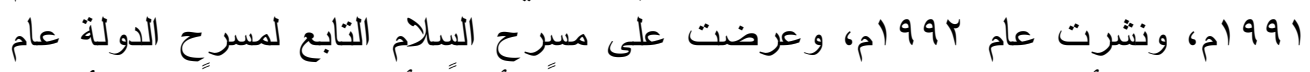

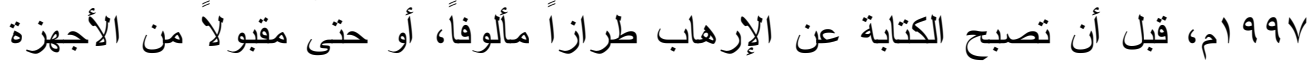

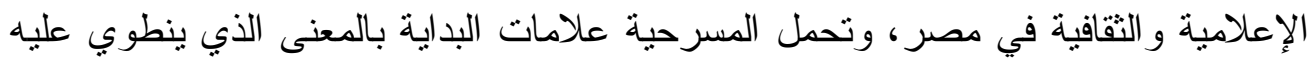

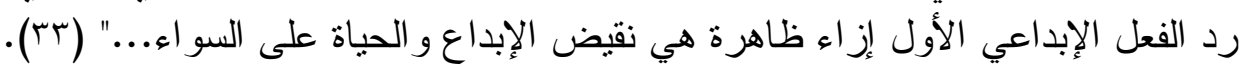

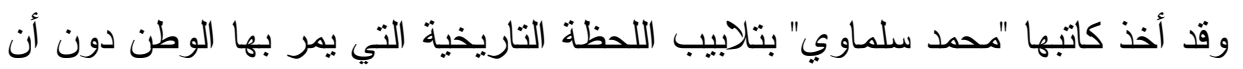

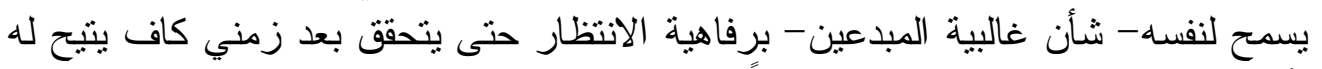
تأمل القضية عن بعد قبل تتاولها در امياً"(ع).

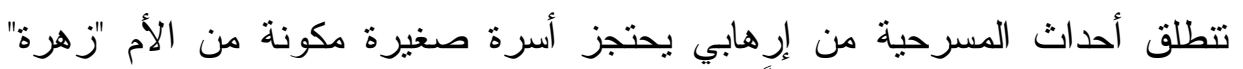

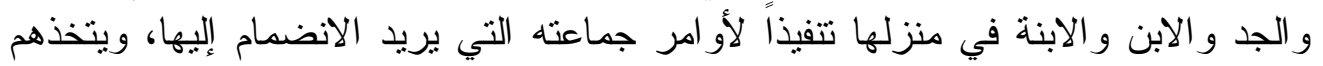

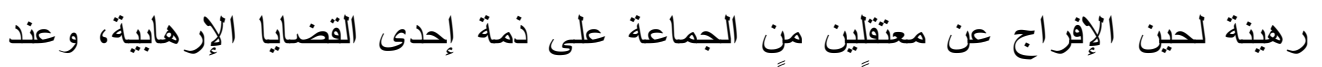

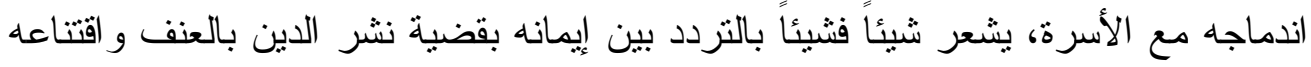

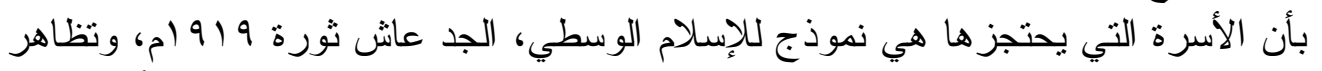

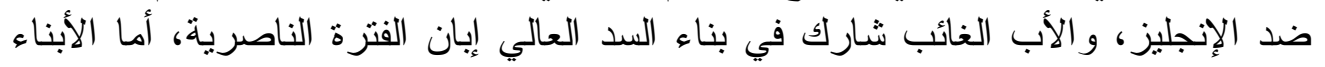

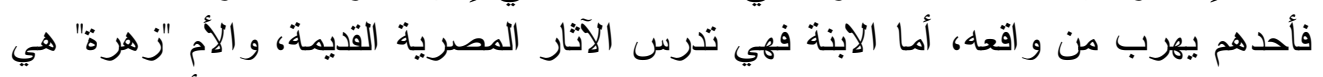

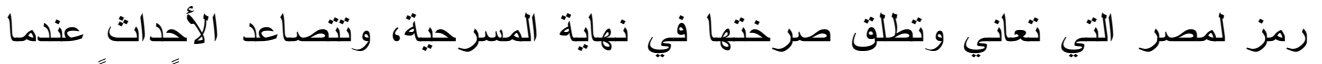

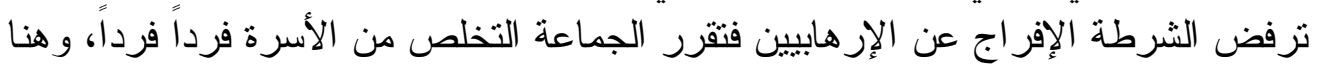

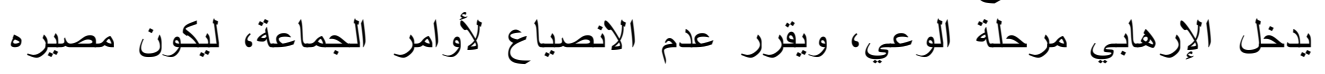

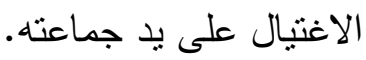

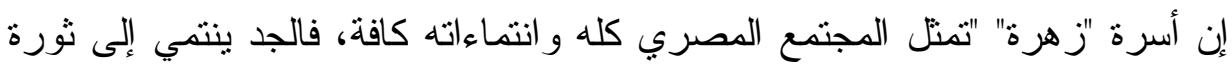

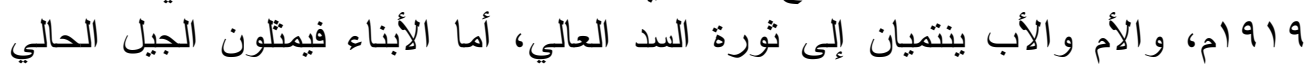

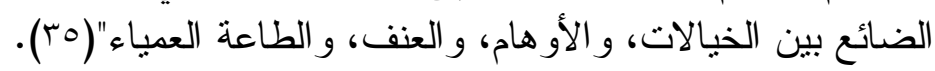

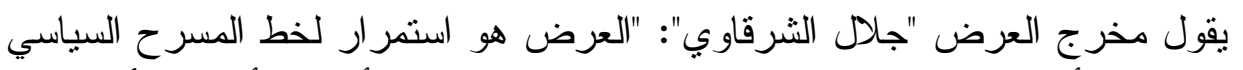

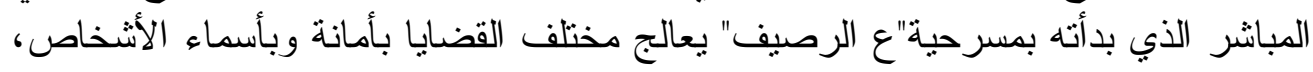

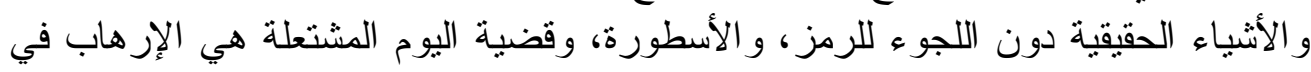

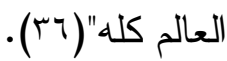

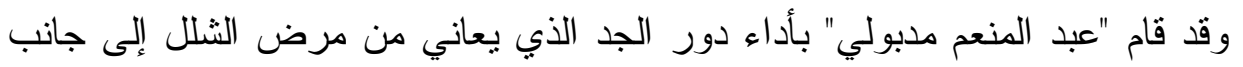

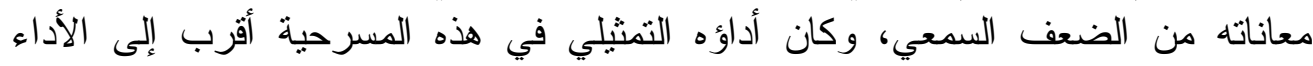

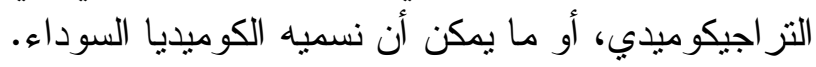


وقد لجأ "مدبولي" إلى إثارة الضحك في هذه المسرحية من خلال التلاعب بالألفاظ

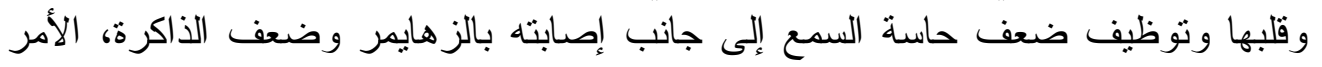
الذي يجعله يتحدث إلى الإزهابي "محمد" على أساس أنه "أحمد" حفيده، على الرئ الرغم منتهديده له بالسلاح(*). "الجد : إزاي يا ولا أنت تهدد أمك بالمسدس؟ كل ده من الهباب البلابيع اللي

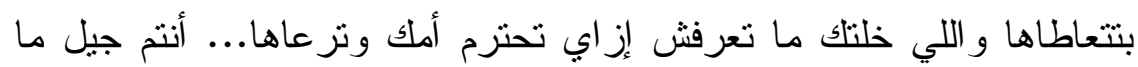
يعرفش ربنا صحيح... يا أبني دي أمك.... عارف يعني إيه أمك؟ أكئ محمد (يصر خ) دي موش أمي...

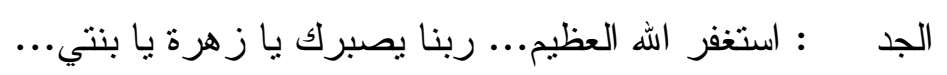

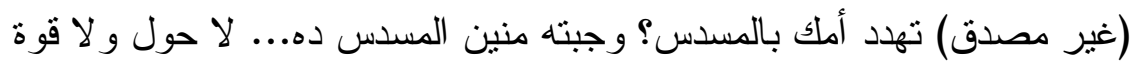
إلا باله... الحق عليكي يا "زهرة" يا بنتي أنك بتديله مصروف منين يروح يشتري بيه مسدسات وبنادق... إخص عليك ولد"(rv).

كما عاش "مدبولي" لحظات من التأمل وهو يعود بالذاكرة إلى الماضي؛ ليعقد مقارنة

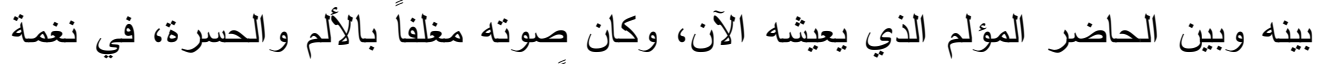

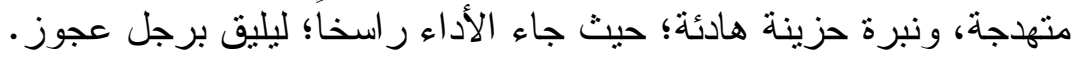

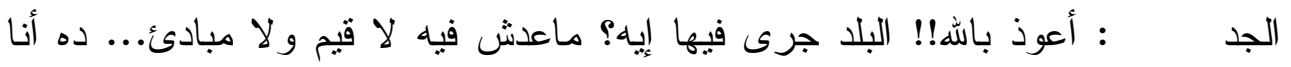
مكنتش أقدر أرفع عيني في وش أبويا، مرة روحنا أنا ومجموعة من زملائي

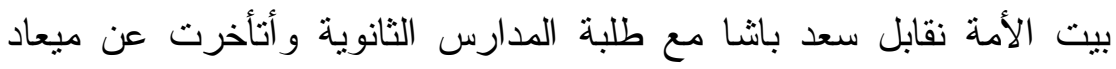

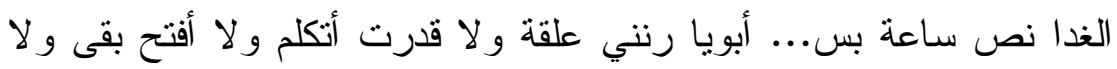
حتى أبص في وشه... دلوقتي الأولاد بيتهجموا على أبهاتهم وعايزين

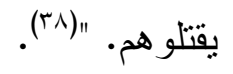

وقد تميزت حركة "مدبولي" في هذا العرض بالاقتصاد الثديد؛ حيث يجلس طوال

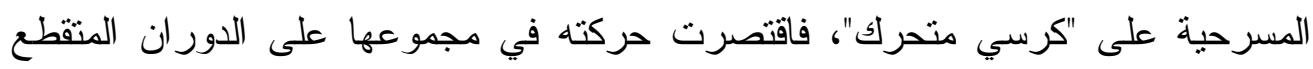
البطيئ في دائرة ضيقة وفق إيقاع الحوار أو "مونولوجاته" المنفردة(*). ولم يخالف هذا النسق الذي يشي بالعجز والحيرة ويجسد فكرة السجن داخل عباءة

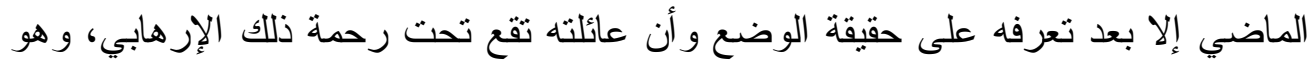

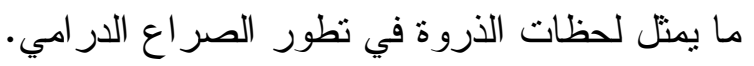


وقد أدى التقابل بين مساحات الحركة الدائرية البطيئة الثابتة في المكان وبين لحظات التغير الفجائية في هذا النسق إلى تكثثف حدة التوتر في هذه اللحظات المشحونة خاصة بعد

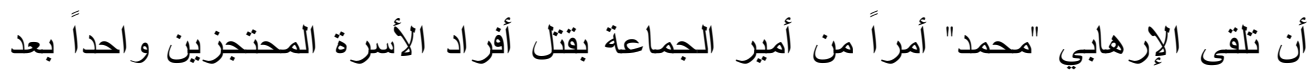
الآخر ، وهنا يتبارى أولئك الأفر اد في التضحية بأنفسهم حماية للآخرين.

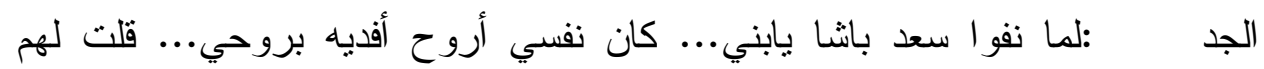

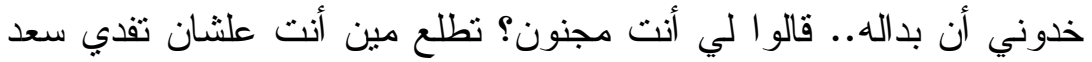

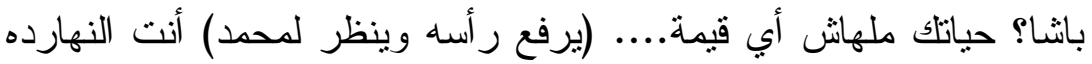

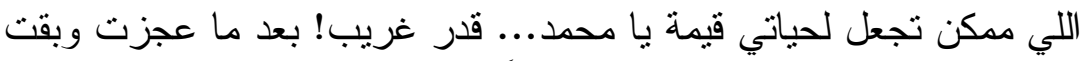

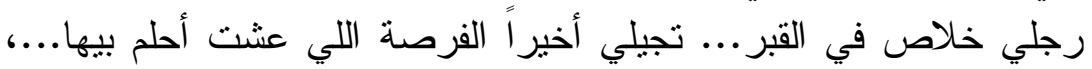

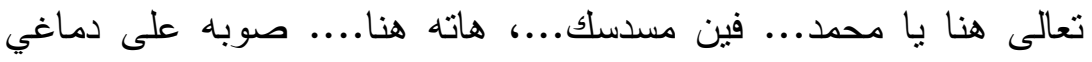

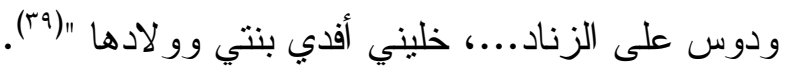

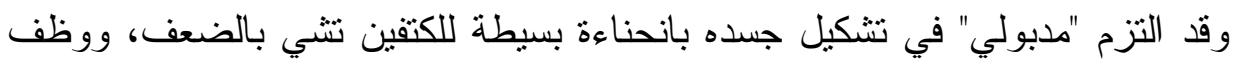

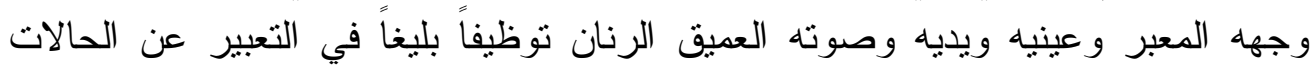

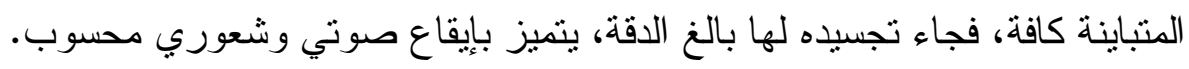

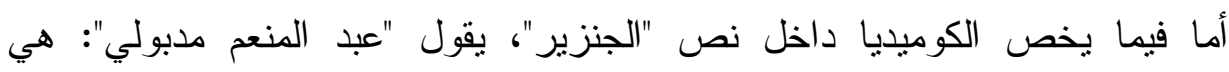

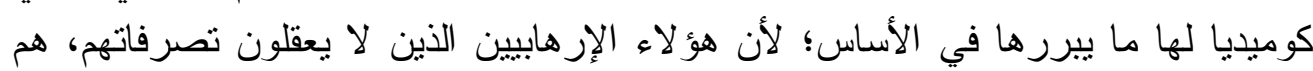

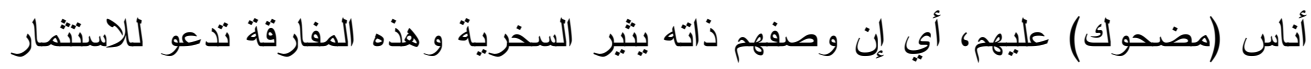

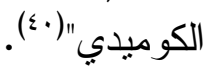

وقد توصلت الباحثة في نهاية البحث إلى مجموعة من النتائج، يمكن إجمالها فيما يأتي:

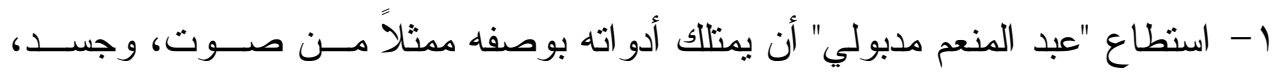

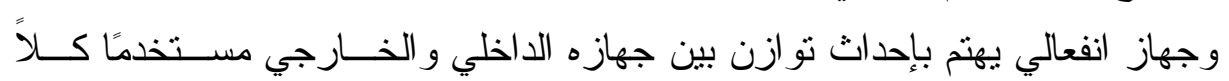

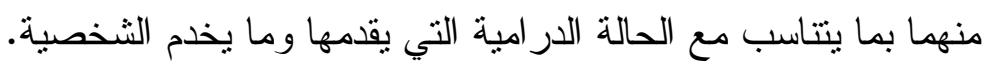

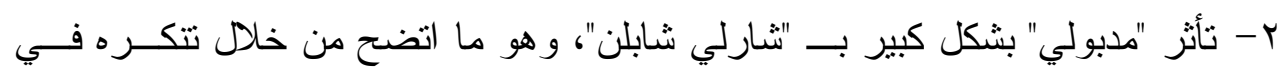
شخصية اللورد الإنجليزي في مسرحية "هاللو شلبي".

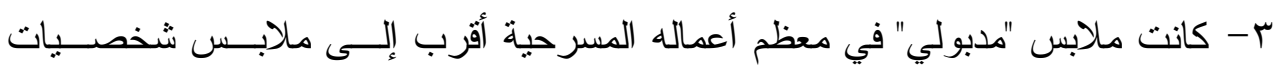

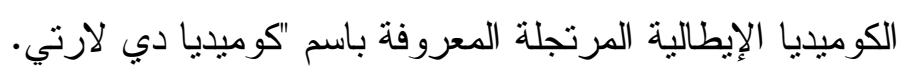

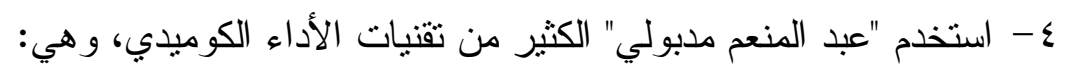


- - المبالغة الحركية، وقد استخدمها في مسرحية "حالة حب". - المفارقة اللفظية، وقد استخدمها في مسرحيات: (حالة حب، هاللو شلبي، و الجنزير).

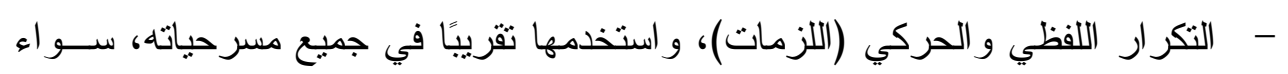
المدرجة في هذا البحث أم غير المدرجة.

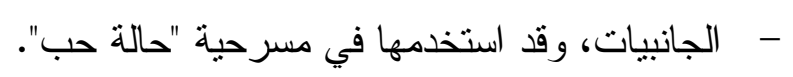
- الانفعالات الصوتية و الحركية، وقد استخدمها في جميع مسرحياته.

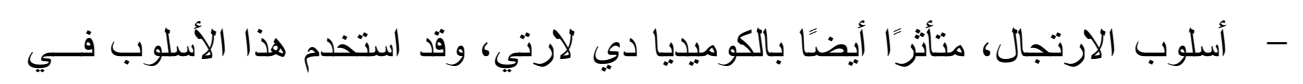

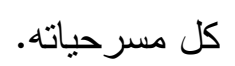

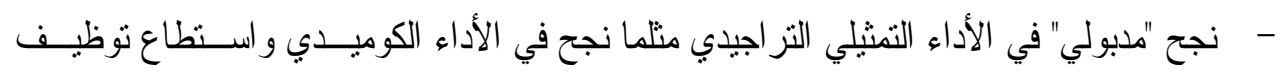
إيماءات وجهه وتتويعات صوته، فأبكانا على قدر ما رسم الابتسامة على الثنفاه.

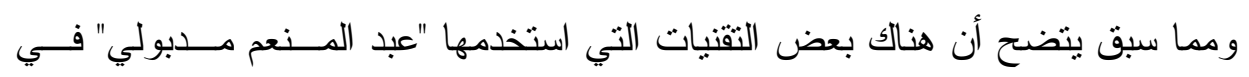

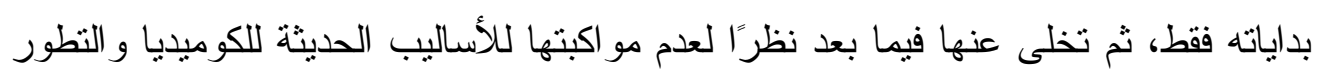

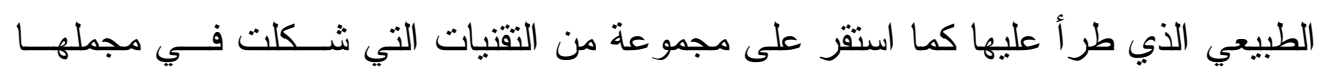

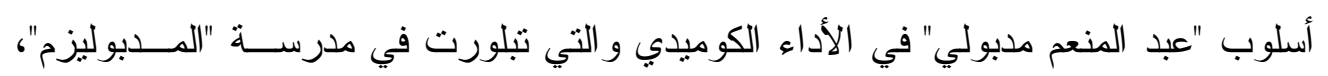

1- التكر ار وصناعة اللزمات اللفظية و الحركية.

r- المفارقة اللفظية و المفارقة الدر امية التقليدية. ץ- الاعتماد على تغيير الإيقاعات الصوتية و الحركية. ع - الانفعالات الصوتية و الشعورية. ه- استخدام الارتجال متأثرًا بفناني كوميديا دي لارتي. لاتئ. 
ملحق صور

مسرحية "حالة حب":

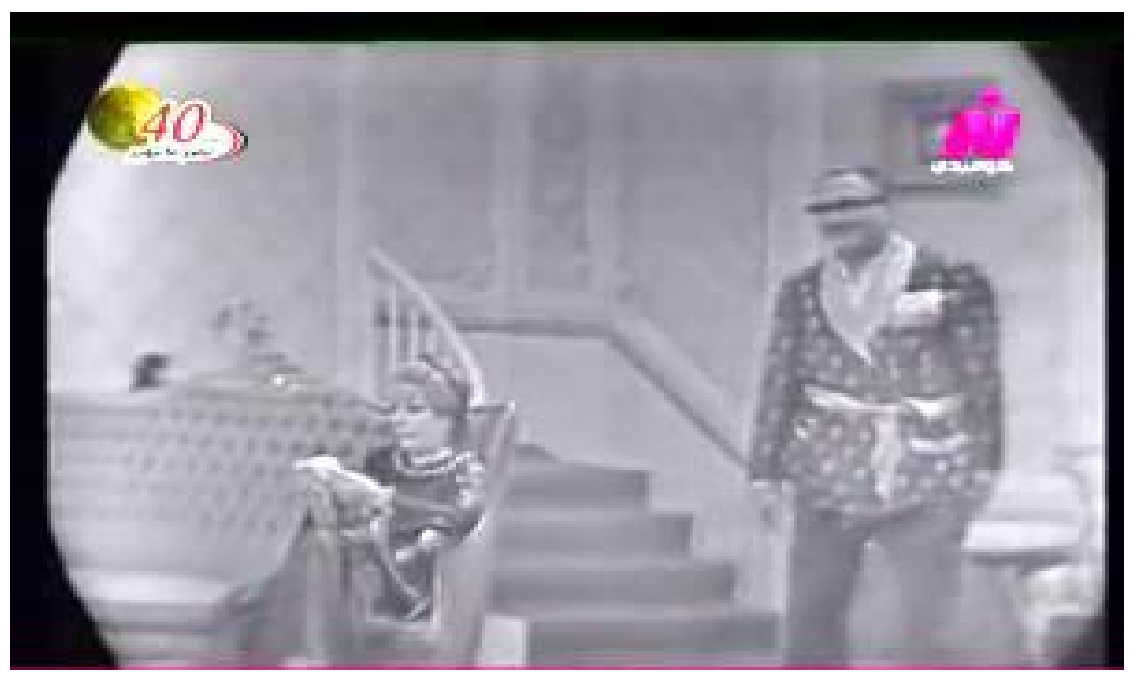

صورة (1)

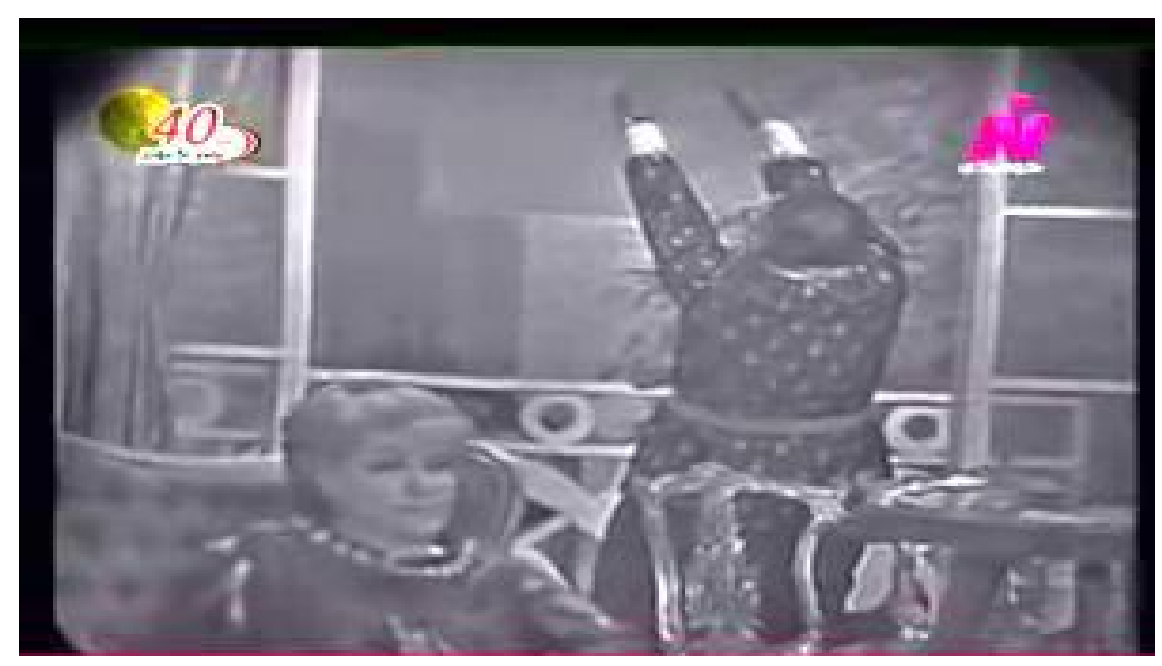

صورة (r) 


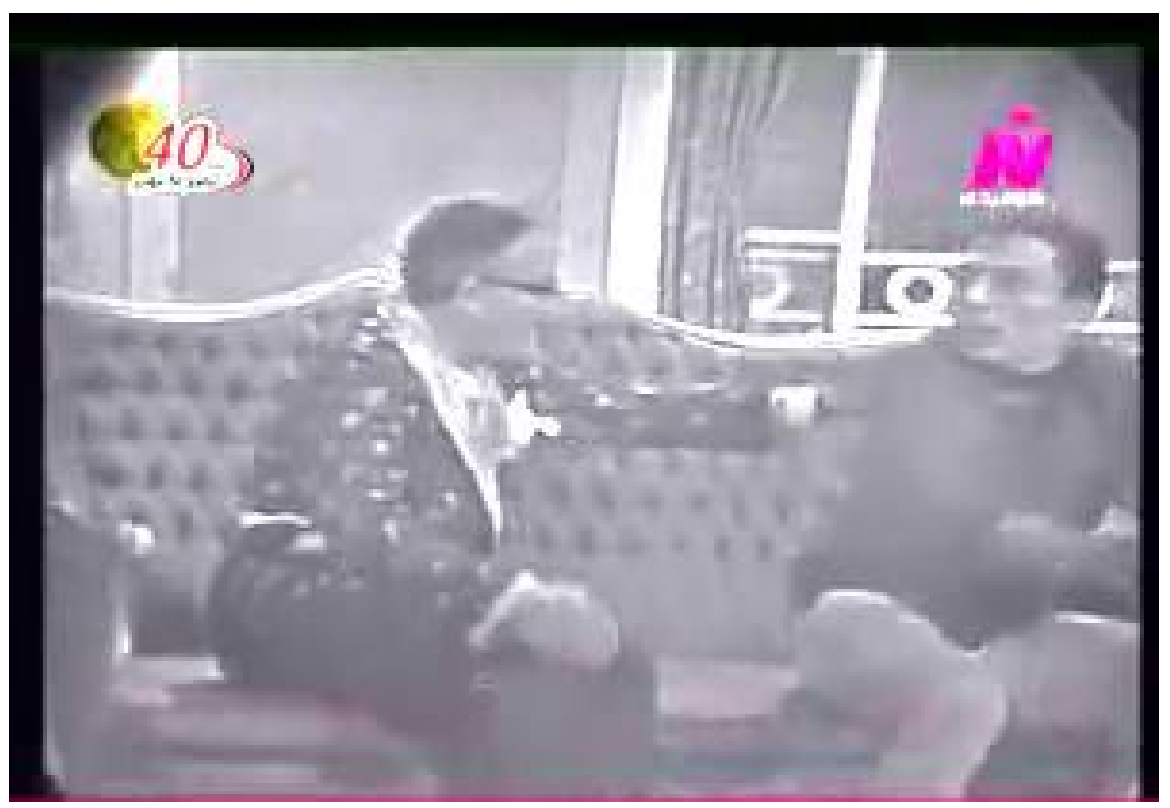

صورة ("ا)

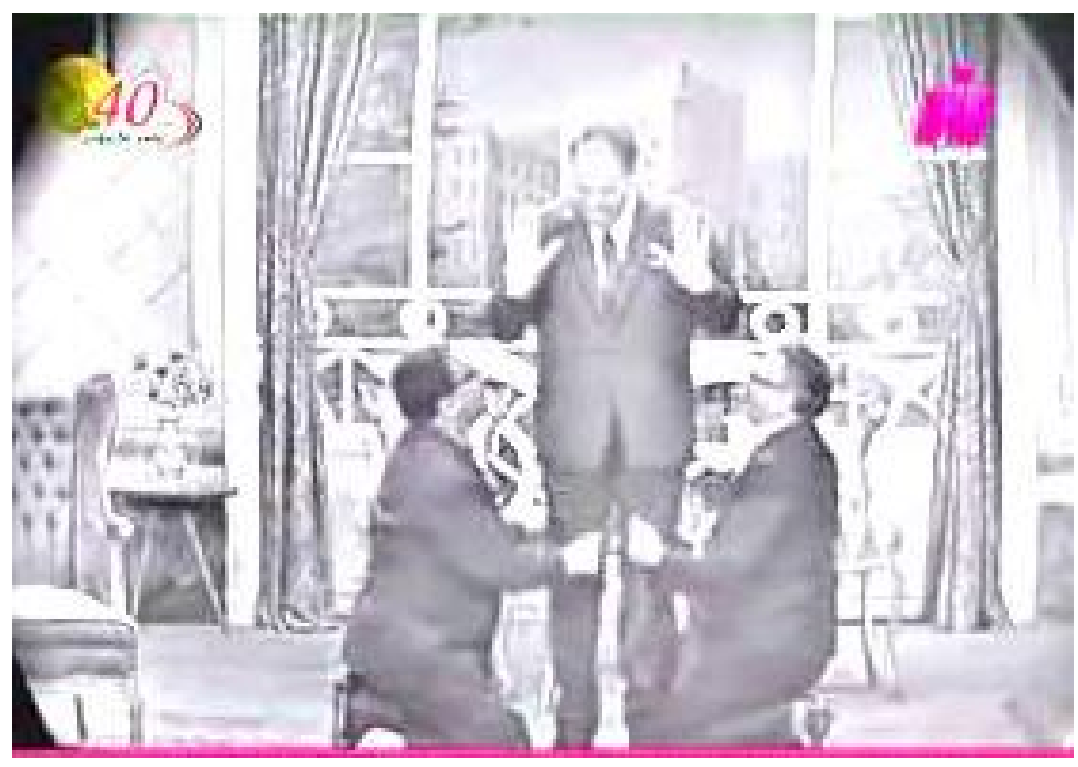

صورة (£) 


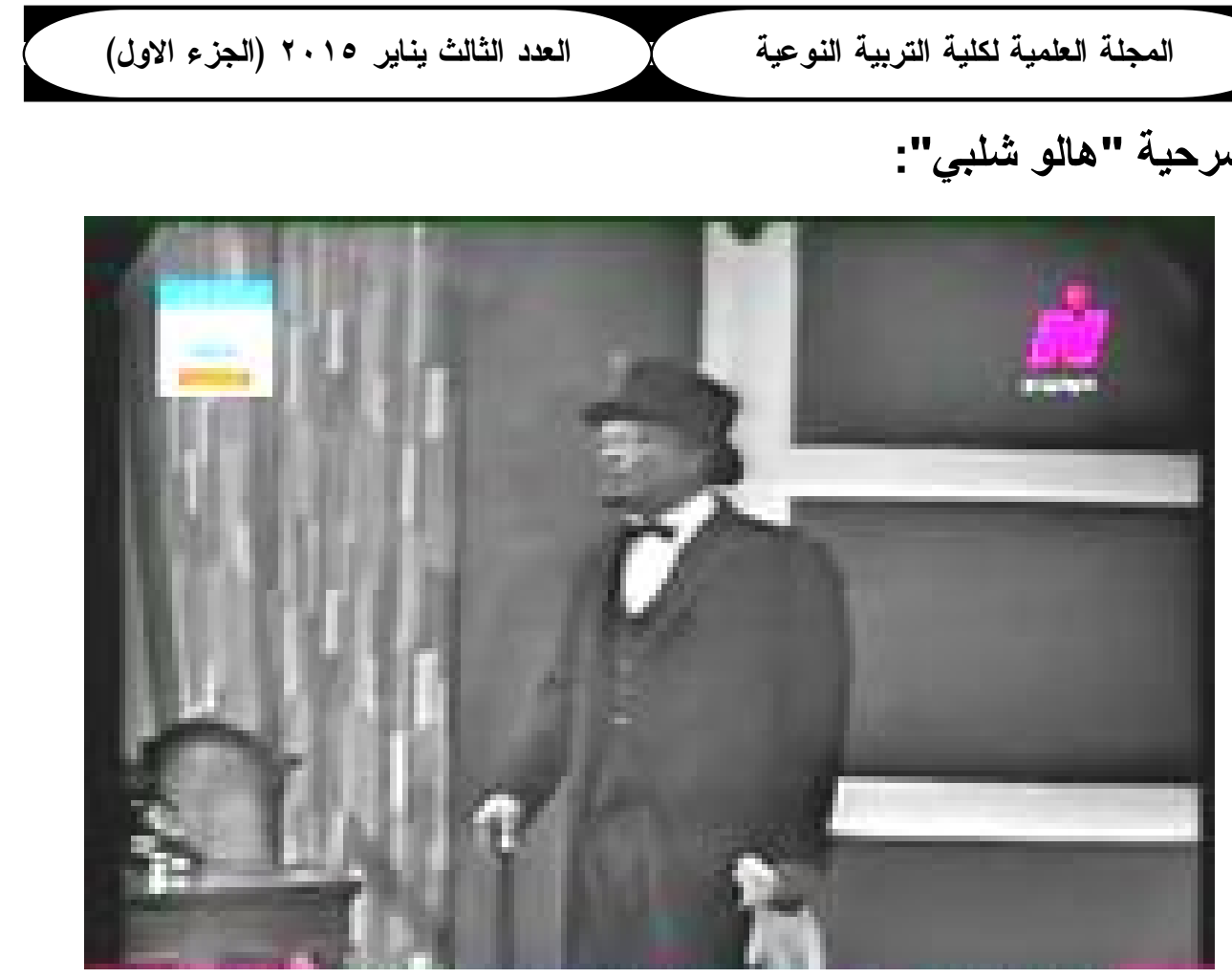

صورة (0)

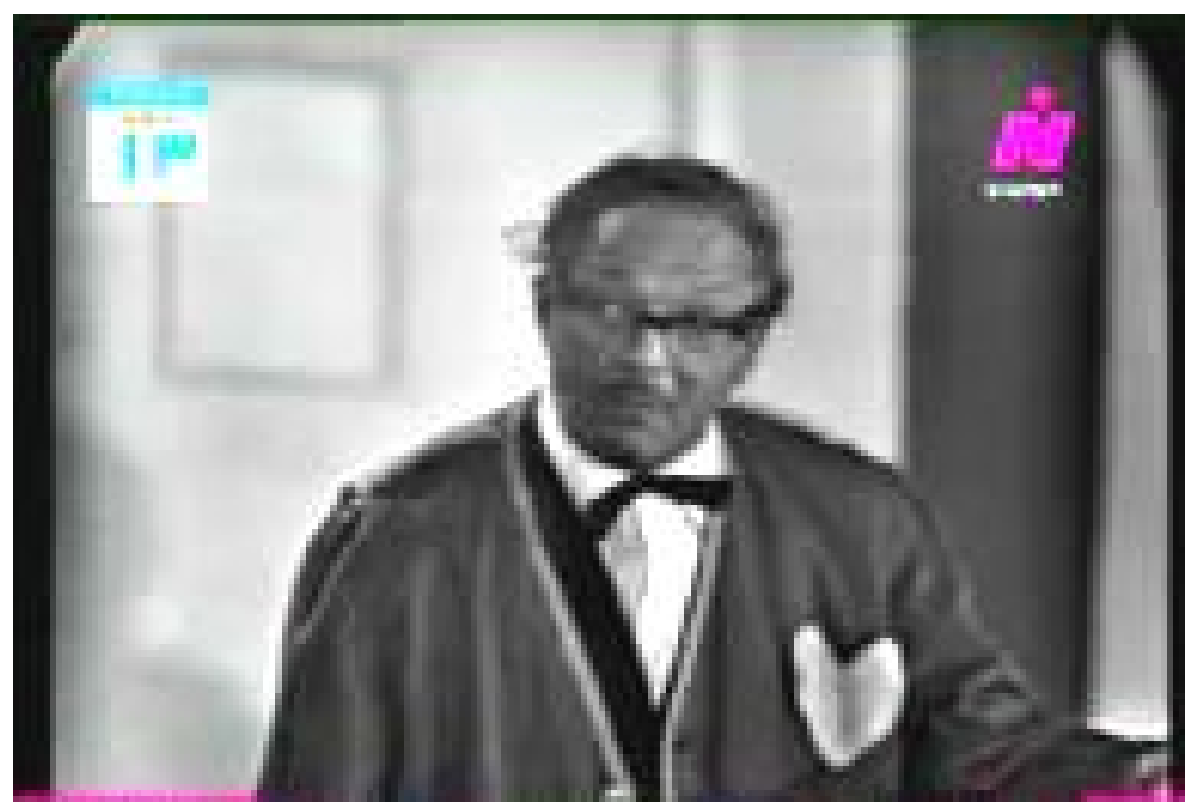

صورة (T) 


\section{المجلة العلمية لكلية التربية النوعية}

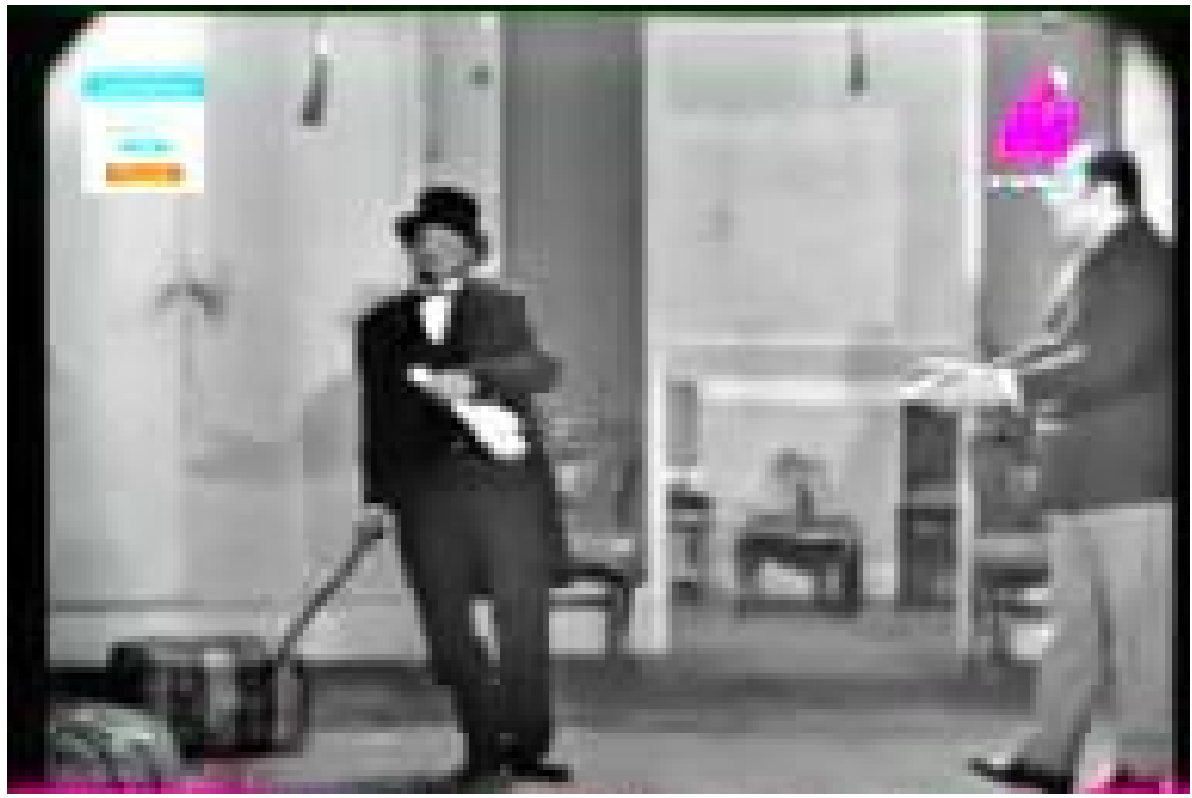

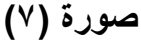

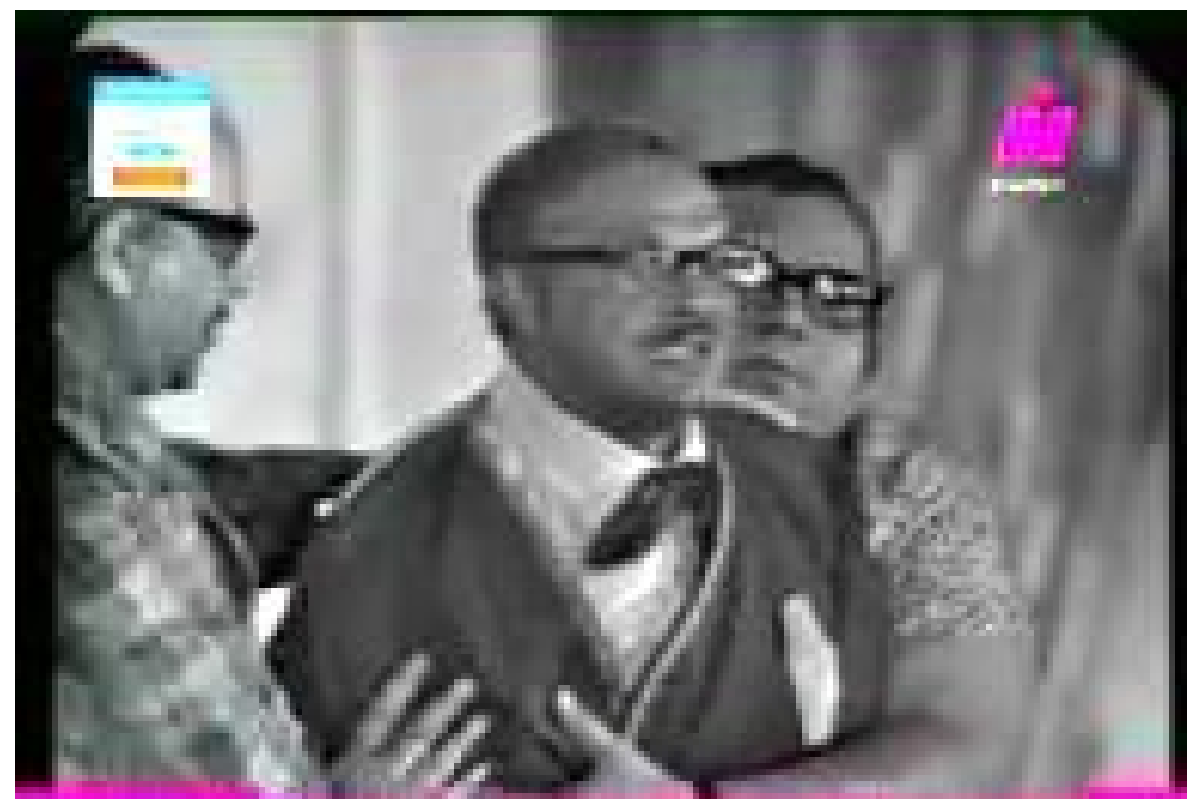

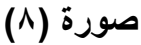




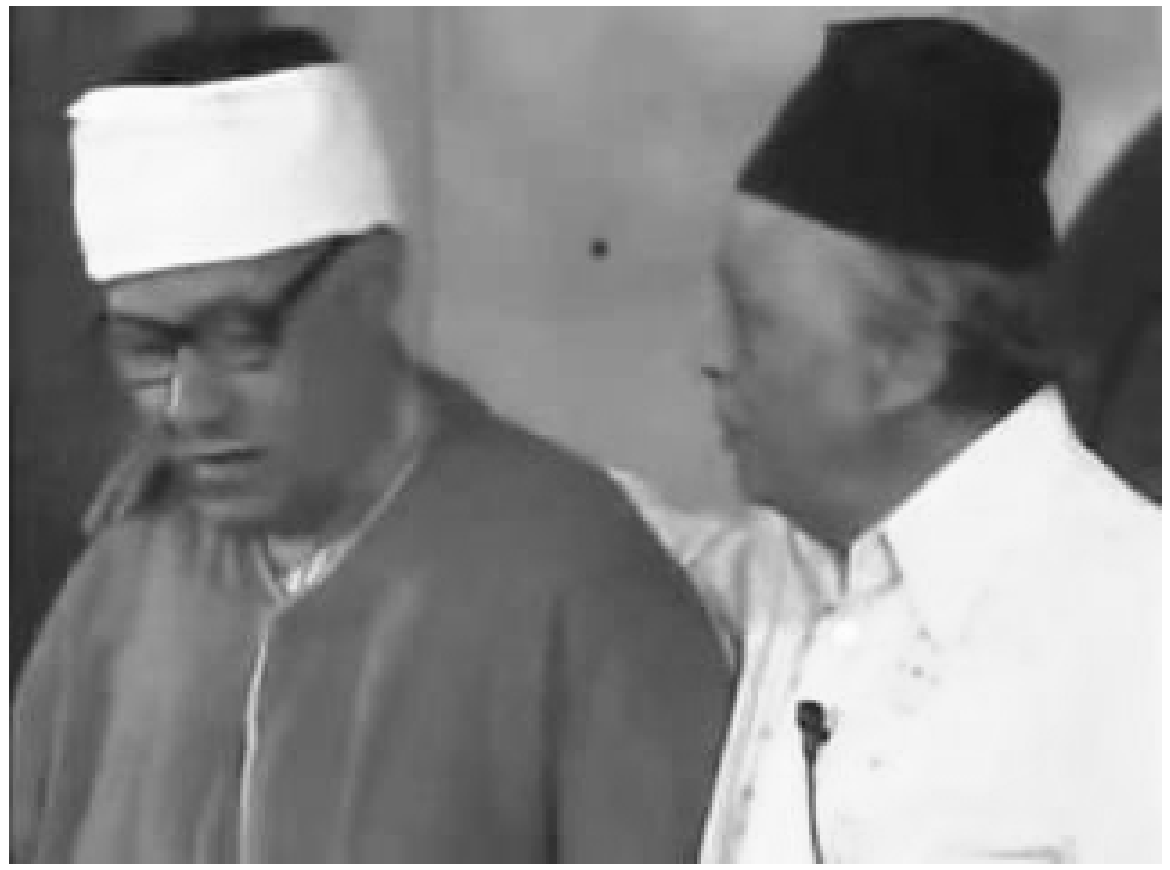

صورة (9)

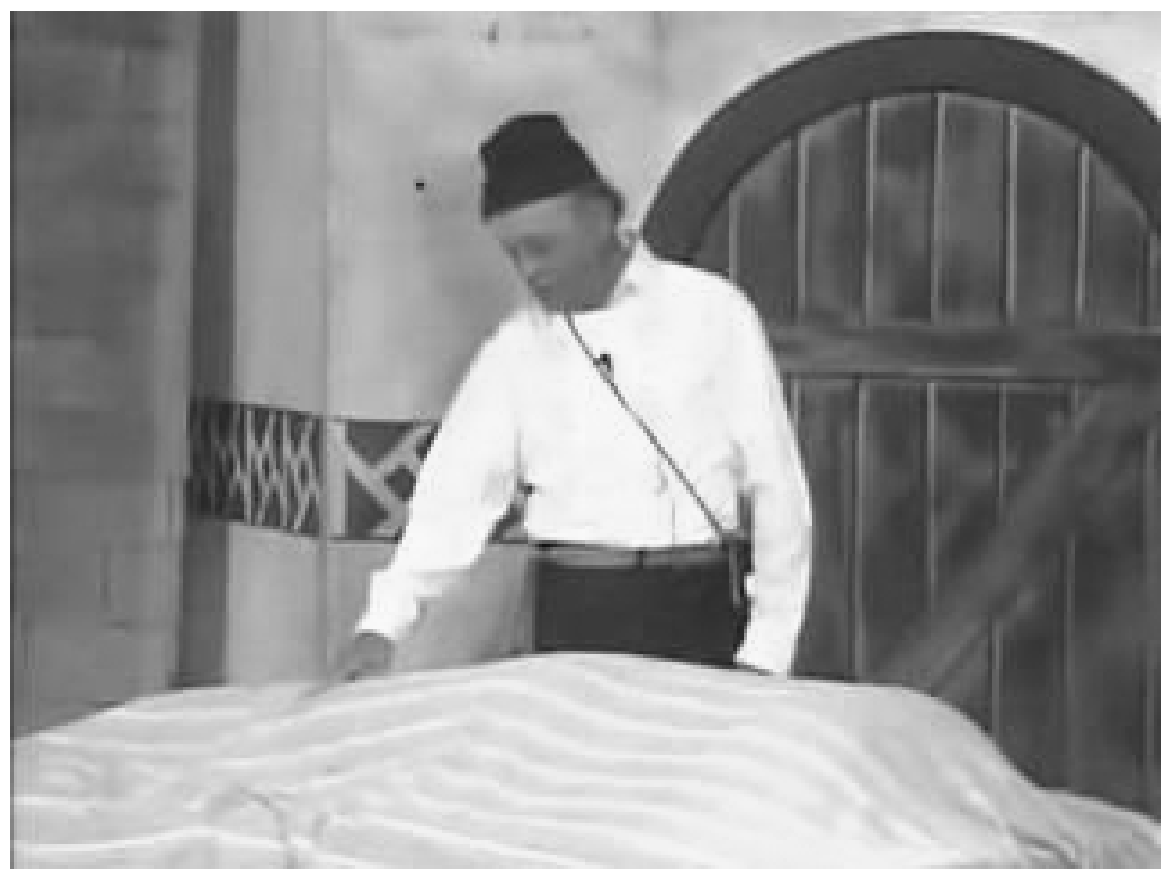

صورة (·) 

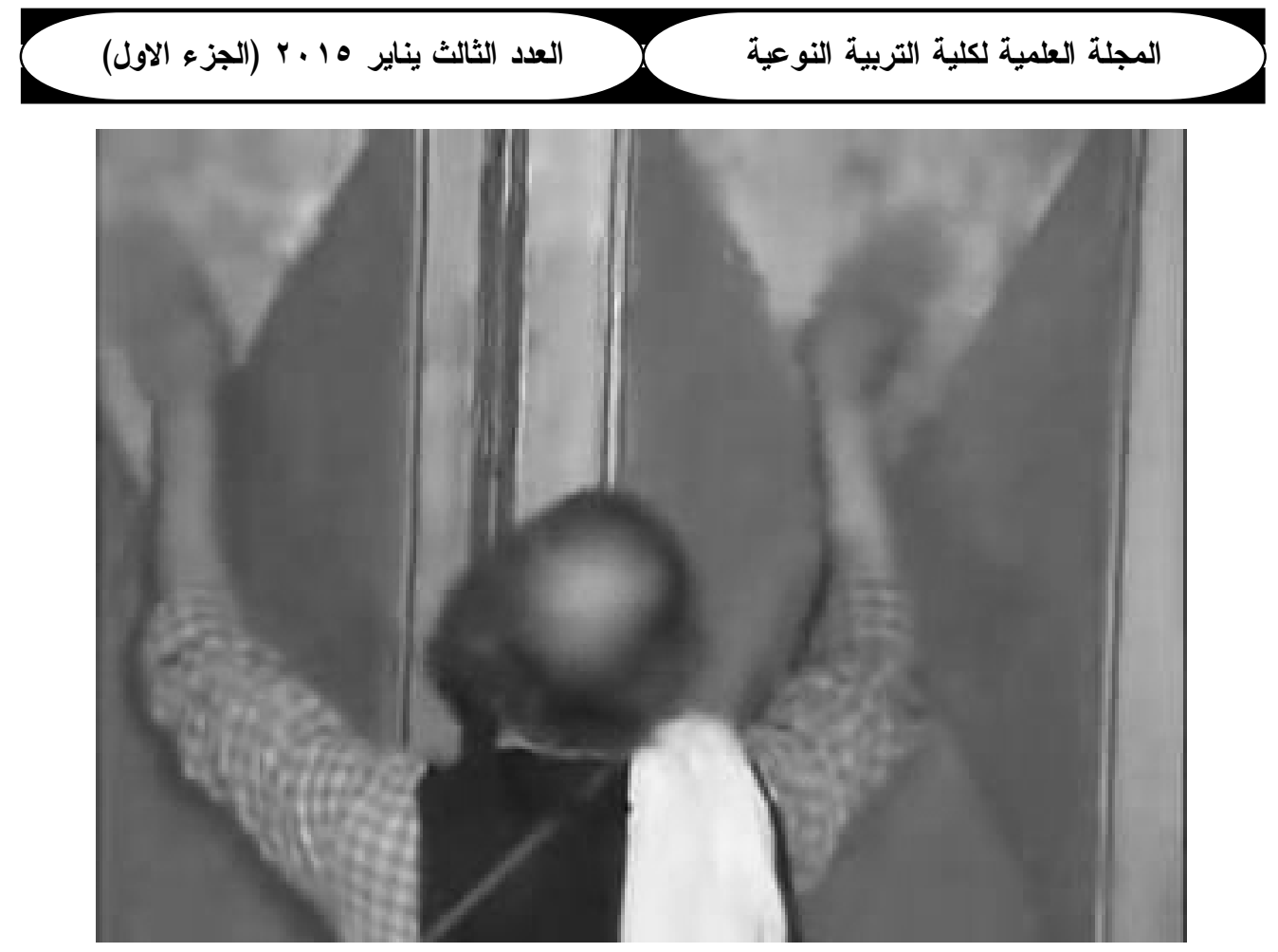

صورة (11)

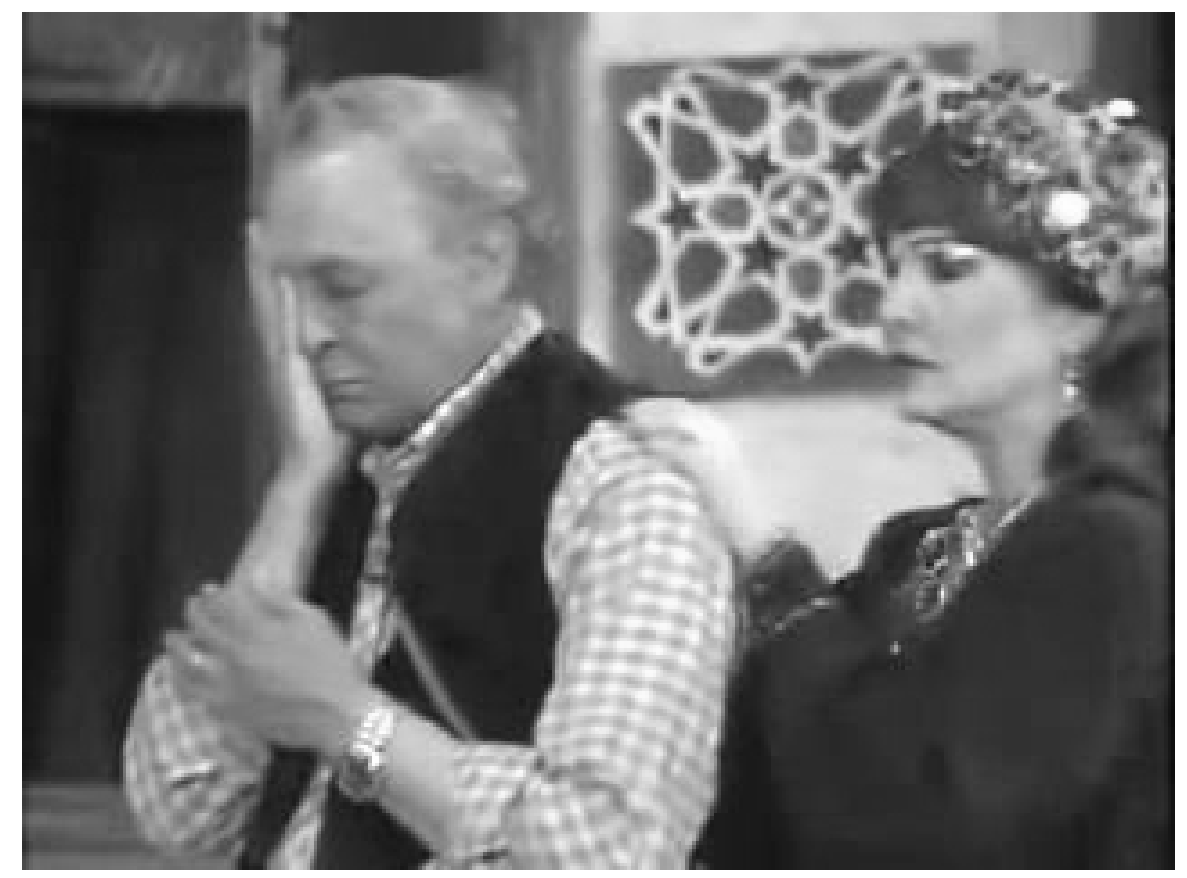

صورة (Y) 


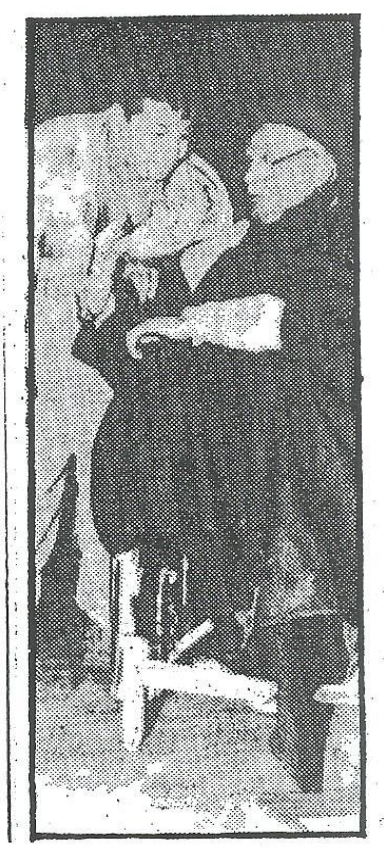

$$
\text { صورة رقم (T) - (I ) }
$$

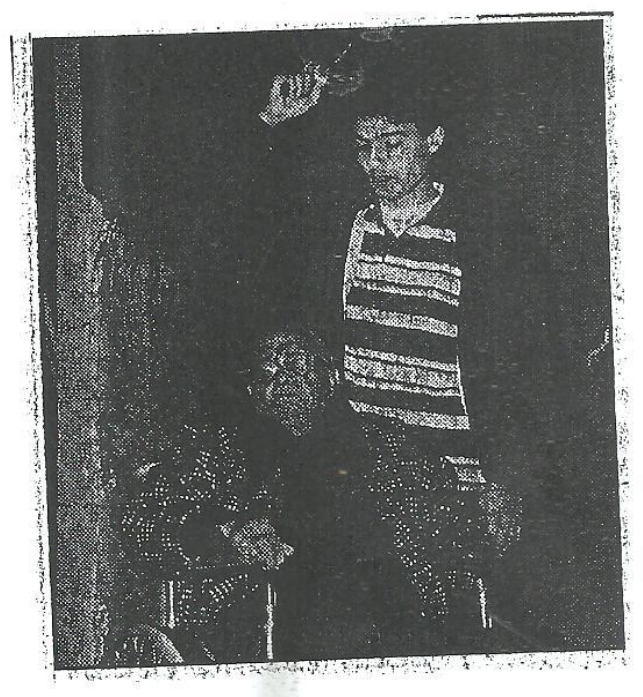

صورة رقم (؛ ( ) 
(*) رانيا فتح الله: أمينة رزق رائدة من رائدات المسرح المصري- دراسة في تطور أداء الممثلمجلة كلية الآداب، جامعة بنها، يوليو ^ ـ. r.

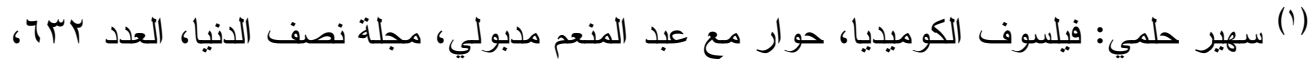

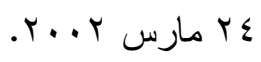

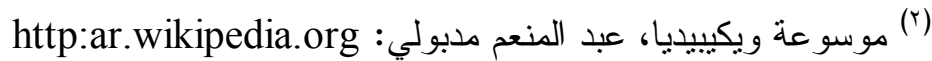

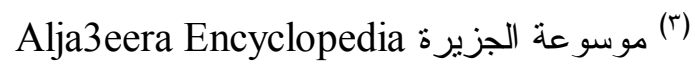

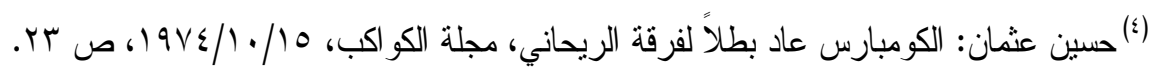

(0) أسهير حلمي: فيلسوف الكوميديا، مرجع سبق ذكره.

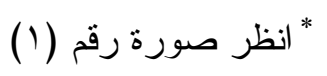

(?) سعد ظلام: الإضحاك في مسرح شوقي، مجلة الفنون، العيئة المصرية العامة للكتاب، القاهرة،

$$
\text { .7V מ } 19 \vee 9
$$

(") سمير خفاجي: مسرحية "حالة حب"، حوار مأخوذ من أسطوانة (CD)، إخراج فؤاد المهندس،

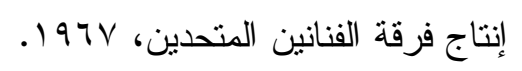

$$
\text { (^) المصدر السابق. }
$$

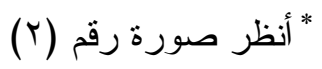

$$
\text { (9) (1) (المصدر السابق. }
$$

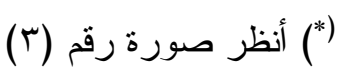

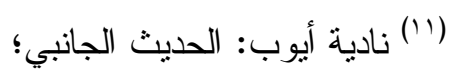

http://www.proz.com

(') (I) سمير خفاجي، مسرحية "حالة حب"، مصدر سبق ذكره.

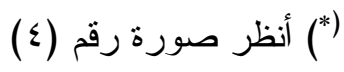

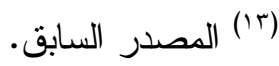

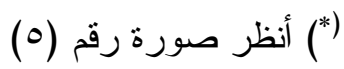

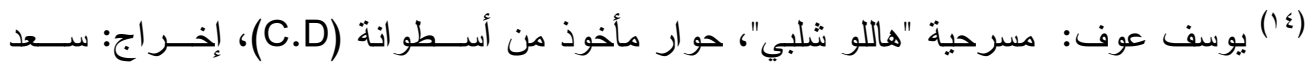

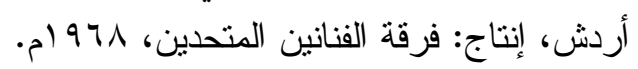

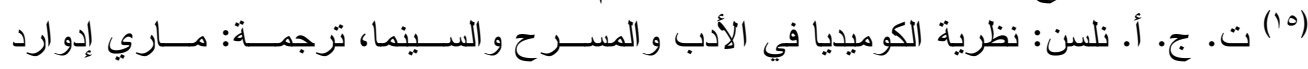

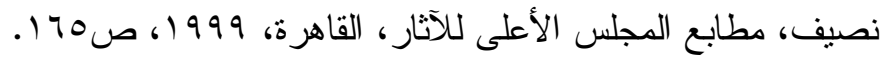


(1) (1) يوسف عوف: مسرحية "هاللو شلبي"، مصدر سبق ذكره.

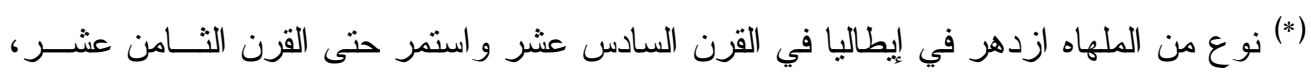
وكان عمادها الارتجال أثناء التثنيل لا النص المدون، وكان كل ممثل يكرس حياته لإجادة

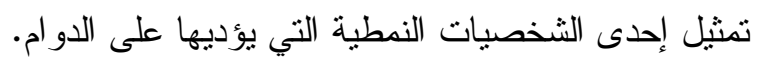

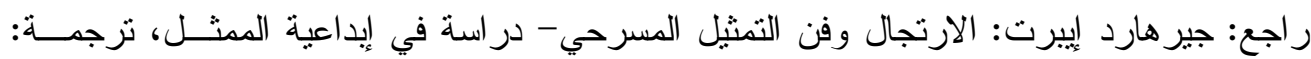

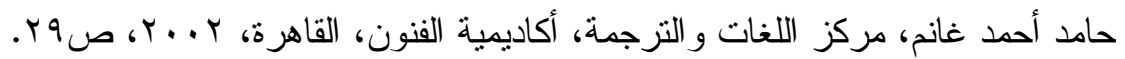
(1) يوسف عوف: مسرحية :هاللو شلبي"، مصدر سبق ذكره.

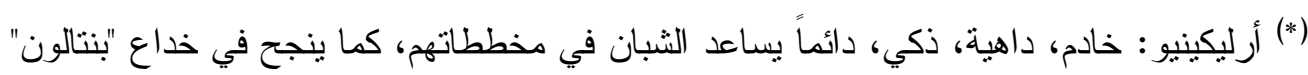
وملابسه طقم مخطط بمربعات.

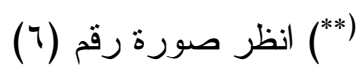
(^’) هنري برجسون: الضحك، ترجمة: سامي الدروبي، الهيئة المصرية العامة للكتاب، القــاهرة،

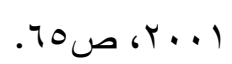

(') (19) سهير حلمي: فليسوف الكوميديا، مرجع سبق ذكره.

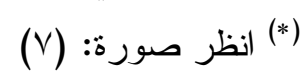

(r.) يوسف عوف: مسرحية "هاللو شلبي"، مرجع سبق ذكره.

$$
\text { (r) (r) (r) المصدر السابق. }
$$

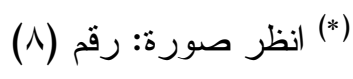

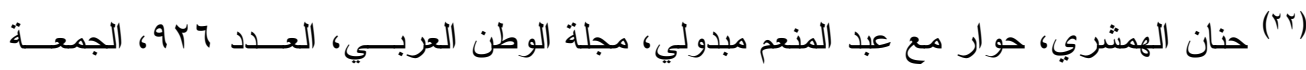

$$
\text { (r) }
$$

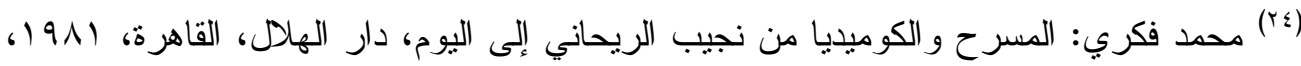

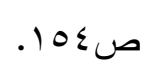

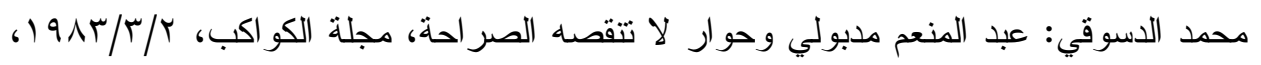

$$
\text { ص } 10 .
$$

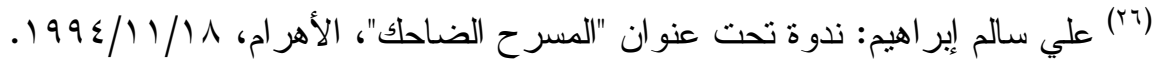

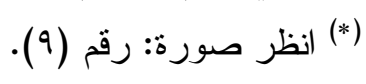

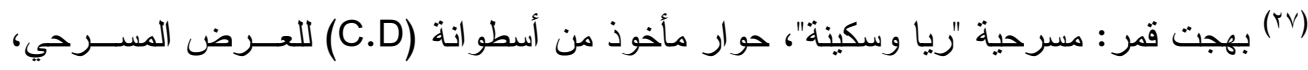

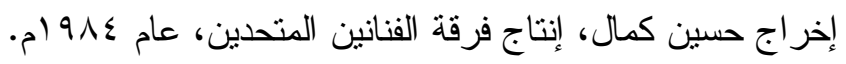




$$
\begin{aligned}
& \text { (ㅅ) }
\end{aligned}
$$

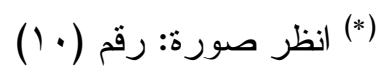

$$
\begin{aligned}
& \text { (ra) }
\end{aligned}
$$

: أور اق قديمة، عبد المنعم مدبولي والجثــة الأونطـــة، الســنيما و النـــاس،

$$
\begin{aligned}
& \text {. }
\end{aligned}
$$

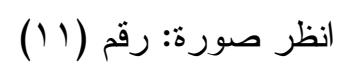

بهجت قمر ، مسرحية "ريا وسكينة"، مصدر سبق ذكره.

$$
\begin{aligned}
& \text { (*) انظر صورة: رقم (ז') } \\
& \text { (rr) المصدر السابق. }
\end{aligned}
$$

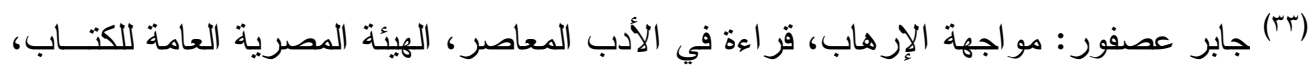

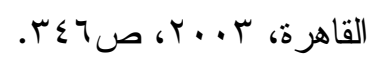

(ז" نهاد صليحة: مقدمة مسرحية "الجنزير"، تأليف: محمد سلماوي، الهيئة المصرية العامة للكتاب،

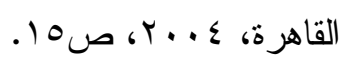

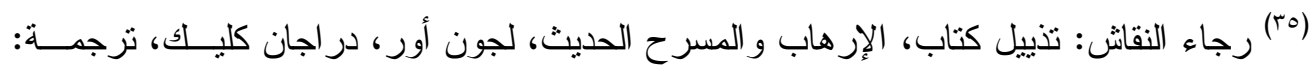

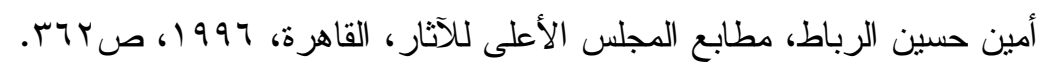

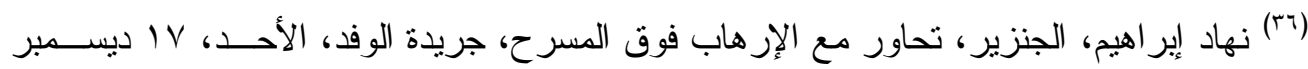

.1990

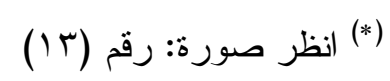

(CV) محمد سلماوي: "الجنزير"، حوار مأخوذ من العرض المسرحي على أسطو انة (C.D)، إخر اج:

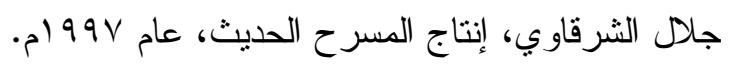

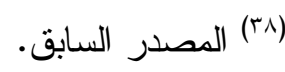

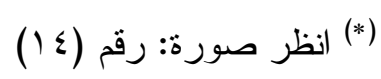

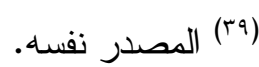

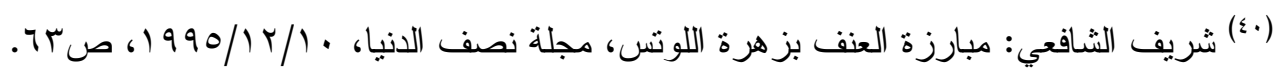

